Article

\title{
Connexin 43 Plays a Role in Pulmonary Vascular Reactivity in Mice
}

\author{
Myo Htet, Jane E. Nally, Andrew Shaw, Bradley E. Foote, Patricia E. Martin and \\ Yvonne Dempsie * \\ Department of Life Sciences, School of Health and Life Sciences, Glasgow Caledonian University, \\ Glasgow G4 0BA, UK; Myo.Htet@gcu.ac.uk (M.H.); J.E.Nally@gcu.ac.uk (J.E.N.); andrew1994@live.co.uk (A.S.); \\ BFOOTE200@caledonian.ac.uk (B.E.F.); patricia.martin@gcu.ac.uk (P.E.M.) \\ * Correspondence: yvonne.dempsie@gcu.ac.uk; Tel.: +44-141-273-1930
}

Received: 23 April 2018; Accepted: 20 June 2018; Published: 27 June 2018

\begin{abstract}
Pulmonary arterial hypertension (PAH) is a chronic condition characterized by vascular remodeling and increased vaso-reactivity. PAH is more common in females than in males $(\sim 3: 1)$. Connexin (Cx) 43 has been shown to be involved in cellular communication within the pulmonary vasculature. Therefore, we investigated the role of $\mathrm{C} x 43$ in pulmonary vascular reactivity using $C \times 43$ heterozygous $\left(C \times 43^{+/-}\right)$mice and ${ }^{37,43}$ Gap27, which is a pharmacological inhibitor of $C \times 37$ and Cx43. Contraction and relaxation responses were studied in intra-lobar pulmonary arteries (IPAs) derived from normoxic mice and hypoxic mice using wire myography. IPAs from male $C \times 43^{+/-}$ mice displayed a small but significant increase in the contractile response to endothelin-1 (but not 5 -hydroxytryptamine) under both normoxic and hypoxic conditions. There was no difference in the contractile response to endothelin-1 (ET-1) or 5-hydroxytryptamine (5-HT) in IPAs derived from female $\mathrm{C} x 43^{+/-}$mice compared to wildtype mice. Relaxation responses to methacholine (MCh) were attenuated in IPAs from male and female $C \times 43^{+/-}$mice or by pre-incubation of IPAs with ${ }^{37,43}$ Gap27. $\mathrm{N}_{\omega}$-Nitro-L-arginine methyl ester (L-NAME) fully inhibited MCh-induced relaxation. In conclusion, $\mathrm{Cx} 43$ is involved in nitric oxide (NO)-induced pulmonary vascular relaxation and plays a gender-specific and agonist-specific role in pulmonary vascular contractility. Therefore, reduced Cx43 signaling may contribute to pulmonary vascular dysfunction.
\end{abstract}

Keywords: pulmonary arterial hypertension (PAH); connexin43 (Cx43); gap junction; vascular reactivity; nitric oxide; serotonin; endothelin-1; isoprenaline

\section{Introduction}

Pulmonary arterial hypertension (PAH) is a progressive disease in which the mean resting pulmonary artery pressure rises above $25 \mathrm{mmHg}$ with a mean resting capillary wedge pressure lower than $15 \mathrm{mmHg}$ [1]. This increase in pressure is associated with both constriction and remodeling of the distal pulmonary vasculature and eventually leads to right-sided heart failure. Prognosis is poor and survival has been reported to only $68 \%$ after three years on therapy [2]. PAH is far more common in females than in males ( 3:1) [3]. Dysregulation of cell-to-cell communication particularly between pulmonary artery endothelial cells (PAECs) and pulmonary artery smooth muscle cells (PASMCs) is thought to play an important role in both constriction and remodeling of the pulmonary vasculature in PAH [4]. For example, PAECs from patients with PAH have increased gene and protein expression of tryptophan hydroxylase 1 (Tph1), which is the rate-limiting enzyme in the synthesis of 5-hydroxytryptamine (5-HT) [5]. 5-HT causes contraction of pulmonary arteries and proliferation of PASMCs [6]. In addition, PAECs from PAH patients produce decreased amounts of nitric oxide, which is a potent vasodilator that suppresses proliferation of PASMCs [7]. 
Connexins are transmembrane proteins that can oligomerize to form a pore in the cell membrane known as a hemi-channel with small regulatory molecules such as $3^{\prime}, 5^{\prime}$-cyclic adenosine monophosphate (cAMP), adenosine $5^{\prime}$ triphosphate (ATP), calcium $\left(\mathrm{Ca}^{2+}\right)$, and inositol 1,4,5-triphosphate $\left(\mathrm{IP}_{3}\right)$, which can pass directly through the cell membrane. Hemi-channels on adjacent cells can align to form gap junctions that allow these mediators to pass directly from the cytoplasm of one cell to that of another. Connexins 37 (Cx37), 40 (Cx40), 43 (Cx43), and 45 (Cx45) are expressed in diverse networks throughout the vasculature [8-10]. In the systemic vasculature, connexins have established roles in regulating vascular tone, vascular cell growth, angiogenesis, cell differentiation, and development [11]. Pannexins belong to the same super-family as connexins and also form membrane-associated channels that can mediate the release of small signaling molecules [12]. Pannexin-1 (Panx1) is expressed throughout the vasculature in the endothelium and also in the medial layer of small resistance arteries [13] and has been shown to play an important role in the $\alpha$-adrenoceptor mediated contractile response [14].

Recent evidence suggests that dysregulated connexin signaling is involved in the pathophysiology of PAH. For example, blood outgrowth endothelial cells from patients with PAH show abnormal gap junctional communication. In addition, the nitric oxide synthase (NOS) inhibitor asymmetric dimethyl arginine (ADMA), is upregulated in PAH patients and inhibits gap junctional communication in human PAECs. The effects of ADMA are prevented by over-expression of Cx43 or by treatment with rotigaptide, which enhances connexin coupling [15]. In line with this, Cx37 and Cx40 are down-regulated in PAECs from PAH patients. Restoration of the transcription factor myocyte enhancer factor 2 leads to increased expression of various transcriptional targets including Cx37 and Cx40. It also rescues pulmonary hypertension in experimental models [16]. Mice genetically deficient in Cx40 are protected against hypoxic-induced pulmonary hypertension. Both genetic knockdown and pharmacological inhibition of $\mathrm{Cx} 40$ attenuates hypoxic pulmonary vasoconstriction in the mouse isolated perfused lung [17]. Moreover, contraction to phenylephrine (an $\alpha-1$ adrenoceptor agonist) in pulmonary arteries taken from chronic hypoxic and monocrotaline (MCT) treated rats is inhibited by both ${ }^{37,43}$ Gap27 and ${ }^{40}$ Gap27 (connexin mimetic peptide blockers of Cxs37/ 43 and Cx40, respectively) [18].

Furthermore, $\mathrm{Cx} 43$ has been shown to play a role in 5-HT mediated signaling in the pulmonary vasculature. 5-HT can be synthesized in human PAECs by Tph1 and then released to act on neighboring PASMCs to mediate both proliferation and contraction [6,19-21]. Studies have shown in experiments using co-cultures of rat PAECs and rat PASMCs that 5-HT can pass through myoendothelial gap junctions formed principally by $\mathrm{Cx} 43$ [22,23]. In line with this, 5-HT-induced contraction of isolated rat pulmonary arteries was attenuated by ${ }^{37,43}$ Gap27 [18].

In the current study, we have assessed the role of $\mathrm{Cx} 43$ in pulmonary vascular reactivity using pulmonary arteries from $C x 43$ heterozygous mice $\left(C x 43^{+/-}\right.$mice). Heterozygous mice were used as a complete genetic knockdown of Cx43, which is lethal in mice [24]. In addition to assessing vasoreactivity in $\mathrm{C} x 43^{+/-}$mice, we have also assessed vasoreactivity in the presence of ${ }^{37,43} \mathrm{Gap} 27$. Since PAH is more common in females than males [3], the role of Cx43 in vascular reactivity was assessed in both male and female mice under normoxic conditions. Paradoxically, male mice have previously been shown to develop more pronounced hypoxic-induced PAH than females [25] and, therefore, our hypoxic experiments were conducted in male mice. Gene expression of $C x 37$ (encoded by GJA4), Cx40 (encoded by GJA5), Cx45 (encoded by GJC1), and Panx1 was assessed in pulmonary arteries from $\mathrm{C} x 43^{+/-}$mice along with gene expression of various mediators known to play a role in the development of PAH: Tph1, endothelial nitric oxide synthase (eNOS, encoded by NOS3), and bone morphogenetic receptor type II (BMPRII, encoded by BMPR2). BMPRII mutations have been found in patients with various forms of PAH [26]. Dysregulated bone morphogenetic protein (BMP) signaling is thought to be pivotal to the pathophysiology of PAH [27]. 


\section{Results}

\subsection{Gene Expression of Connexins in Pulmonary Arteries from Cx43 heterozygous Mice}

First, quantitative real time PCR (qPCR) was performed to confirm reduced gene expression of $\mathrm{Cx} 43$ in pulmonary arteries of male and female $C x 43^{+/-}$mice. Cx43 expression was higher in females than in males in both WT and $C x 43^{+/-}$mice (Figure 1A). Afterward, pulmonary arterial gene expression levels of $C x 43$ with $C x 37, C x 40$, and $C x 45$ in wildtype mice were compared. $C x 43$ was the predominant vascular connexin in female mice. In male mice, there was a trend towards $C x 43$ being expressed at greater levels than $C x 37$ and $C x 40$, but this was not significant. $C x 45$ was expressed at lower levels in both male and female mice (Figure 1B).

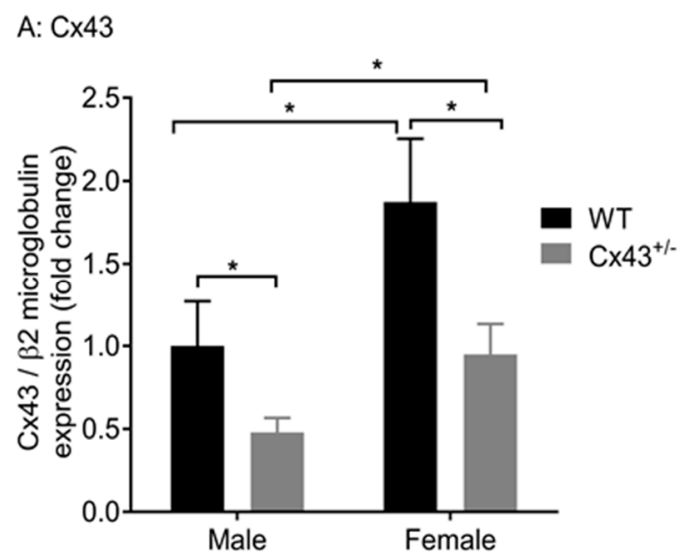

\section{B: Connexin expression levels}

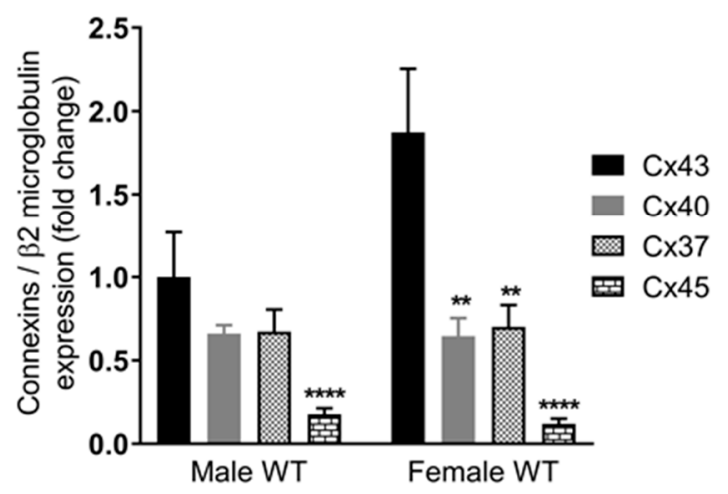

Figure 1. Connexin gene expression in pulmonary arteries from male and female mice. $C x 43$ gene expression is reduced in pulmonary arteries from $C x 43$ heterozygous $\left(C x 43^{+/-}\right)$mice (A). Female mice have increased levels of $C x 43$ compared to males (A). Cx43 is the predominant vascular connexin in female mice while male mice show similar levels of $C x 43, C x 40$, and $C x 37$. $C x 45$ is expressed in lower levels than Cxs 43, 40, and 37 in both male and female mice (B). Data are presented as mean \pm S.E.M. and were analyzed by two-way ANOVA. $n=6$ with each sample run in triplicate. A: ${ }^{*} p<0.05$, B: ${ }^{* *} p<0.01,{ }^{* * * *} p<0.0001$ compared to $C x 43$.

We explored the effects of genetic knockdown of $C x 43$ on gene expression of $C x 37, C x 40, C x 45$, and Panx1, which are all expressed in the vasculature. Male $C x 43^{+/-}$mice displayed reduced gene expression of $C x 37, C x 40, C x 45$, and Panx1 mRNA (Figure 2A-D) when compared to WT littermates. Female $C x 43^{+/-}$mice, however, displayed no changes in gene expression of $C x 37, C x 40, C x 45$, or Panx 1 compared to WT littermates (Figure 2A-D). The housekeeping gene $\beta 2$-microglobulin was expressed at similar levels in all four groups of mice studied (Ct values: male WT $24.9 \pm 0.2$, male $C \times 43^{+/-}$ $24.4 \pm 0.2$, female WT $25.0 \pm 0.2$, female $C x 43^{+/-} 24.6 \pm 0.3, p=0.86$ ) 
A: $\mathrm{C} \times 37$

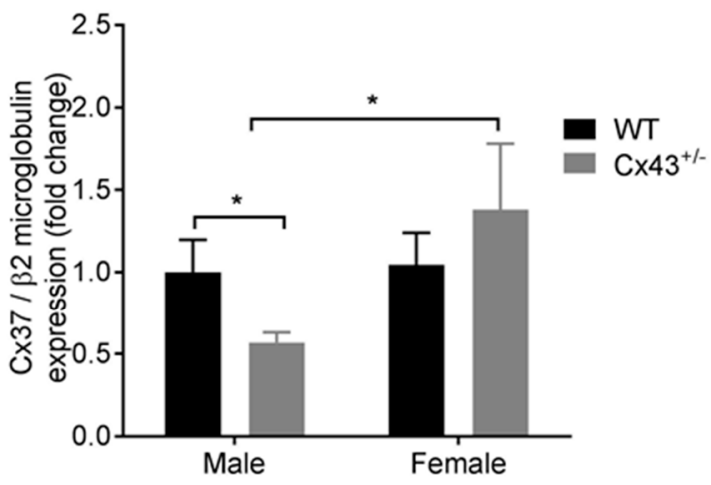

C: $\mathrm{Cx45}$

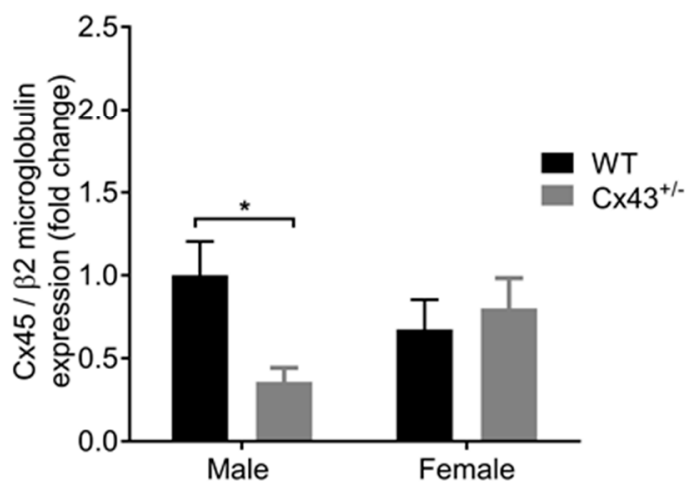

B: $\mathrm{Cx} 40$

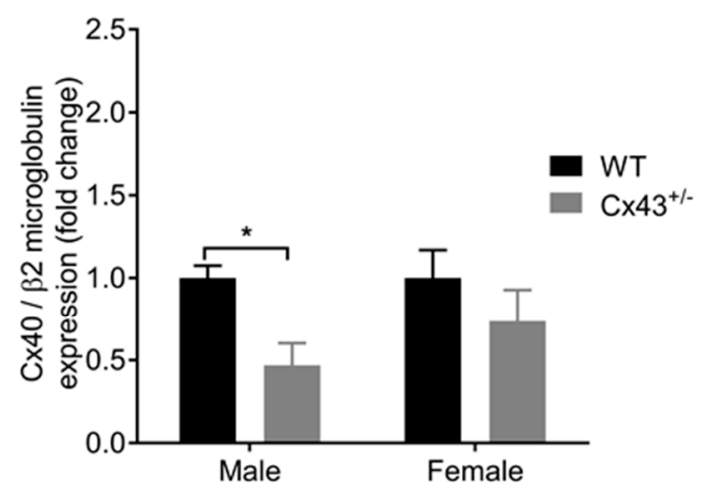

D: Panx1

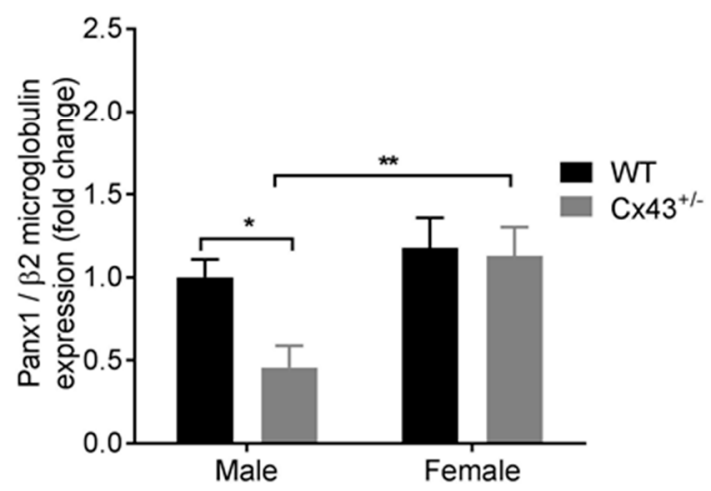

Figure 2. Gene expression of $C x 37$ (A), Cx40 (B), Cx45 (C), and Panx1 (D) in pulmonary arteries from male and female wildtype (WT) and $C x 43$ heterozygous $\left(C x 43^{+-}\right)$mice. Data are presented as mean \pm S.E.M. and were analyzed by two-way ANOVA. ${ }^{*} p<0.05,{ }^{* *} p<0.01, n=6$ per group with each sample analyzed in triplicate.

\subsection{Pulmonary Arterial Contractile Responses}

In the intra-lobar pulmonary arteries (IPAs) of male mice, endothelin-1 (ET-1) was more potent (had a lower median effective concentration or $\mathrm{EC}_{50}$ value) in $C \times 43^{+/-}$mice compared to WT mice (Figure 3A; Table 1). Maximal response to ET-1 ( $\left.E_{\max }\right)$ was, however, unchanged between WT and $\mathrm{C} \times 43^{+/-}$mice. There was no global shift in the concentration response curve (Figure 3A; Table 1). IPAs from male $\mathrm{C} \times 43^{+/-}$mice showed similar contractile responses to 5-hydroxytryptamine (5-HT) as those from WT mice (Figure 3B; Table 1). Contractile responses to both ET-1 and 5-HT were similar in IPAs from female $\mathrm{C} x 43^{+/-}$mice compared to female WT mice (Figure 3C,D; Table 1). 
A.

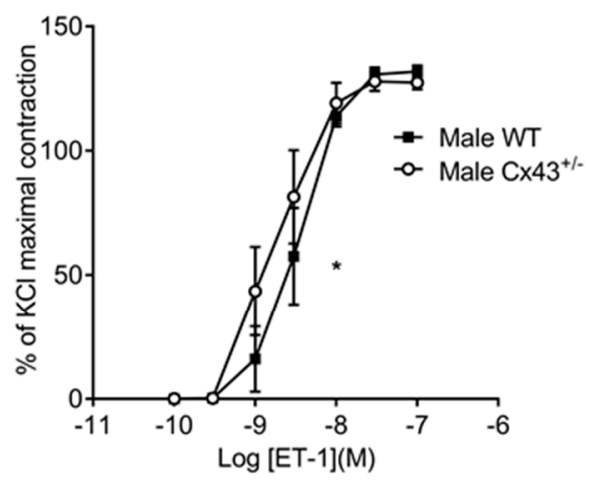

C.

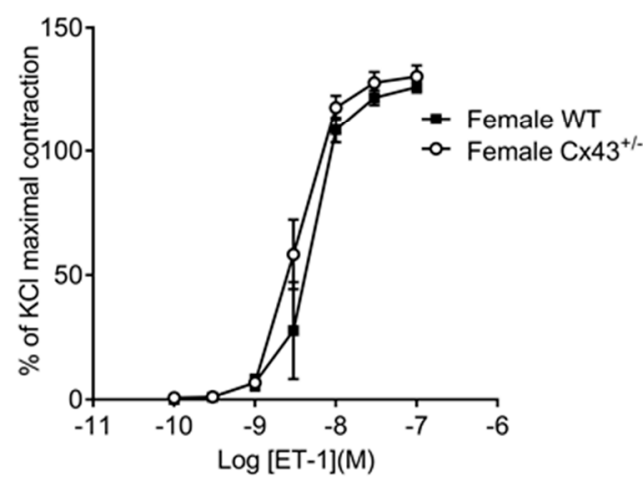

B.

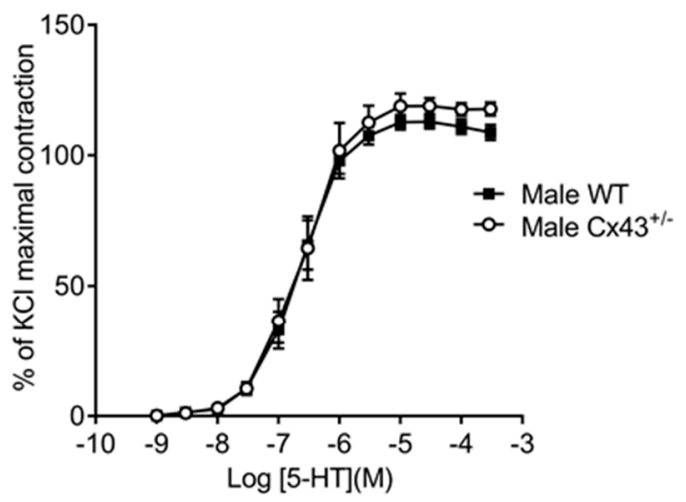

D.

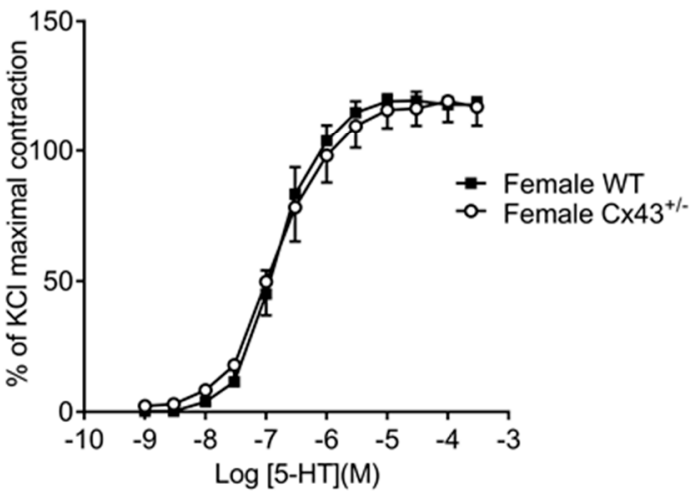

Figure 3. Pulmonary vascular contractility to ET-1 and 5-HT in intralobar pulmonary arteries (IPAs) from male and female wildtype (WT) and $C x 43$ heterozygous $\left(C x 43^{+/-}\right)$mice. ET- 1 was more potent in IPAs from male $\mathrm{C} x 43^{+/-}$mice than WT mice (A). There was no difference in contractile response to 5-HT in IPAs from male WT and C $x 43^{+/-}$mice (B). There was no difference in ET-1 (C) or 5-HT (D) induced contractile response in IPAs from female WT or $C x 43^{+/-}$mice. Data are shown as mean \pm S.E.M. Global differences in concentration response curves were compared by two-way ANOVA. Changes in logarithm of median effective concentration $\left(\log \mathrm{EC}_{50}\right)$ and maximal contractile responses $\left(\mathrm{E}_{\max }\right)$ between two different groups were analyzed by using the Student's $t$-test. ${ }^{*} \mathrm{EC}_{50}$ is significantly $(p<0.05)$ reduced in male $C x 43^{+/-}$mice, $n=5-7$ per group.

Table 1. The contractile effects of ET-1 and 5-HT in IPAs of male and female wildtype (WT) and Cx43 heterozygous $\left(\mathrm{C} \times 43^{+/-}\right)$mice.

\begin{tabular}{|c|c|c|c|c|c|}
\hline Agonists & Groups & $\log \mathrm{EC}_{50}(\mathrm{M})$ & $E_{\max }(\%)$ & $\begin{array}{c}\text { Global Shift in Concentration } \\
\text { Response Curve }\end{array}$ & $n$ \\
\hline ET-1 & $\begin{array}{c}\text { Male WT } \\
\text { Male } C x 43^{+/-}\end{array}$ & $\begin{array}{c}-8.46 \pm 0.08 \\
-8.77 \pm 0.12 *\end{array}$ & $\begin{array}{l}131.8 \pm 2.5 \\
127.4 \pm 2.8\end{array}$ & NS & $\begin{array}{l}6 \\
5\end{array}$ \\
\hline ET-1 & $\begin{array}{c}\text { Female WT } \\
\text { Female } C x 43^{+/-}\end{array}$ & $\begin{array}{l}-8.31 \pm 0.06 \\
-8.48 \pm 0.04\end{array}$ & $\begin{array}{c}126 \pm 2.2 \\
130.3 \pm 4.5\end{array}$ & NS & $\begin{array}{l}5 \\
7\end{array}$ \\
\hline 5-HT & $\begin{array}{c}\text { Male WT } \\
\text { Male } C x 43^{+/-}\end{array}$ & $\begin{array}{l}-6.67 \pm 0.05 \\
-6.64 \pm 0.07\end{array}$ & $\begin{array}{l}112.7 \pm 2.8 \\
118.9 \pm 4.8\end{array}$ & NS & $\begin{array}{l}6 \\
5\end{array}$ \\
\hline 5-HT & $\begin{array}{c}\text { Female WT } \\
\text { Female } C x 43^{+/-}\end{array}$ & $\begin{array}{l}-6.82 \pm 0.05 \\
-6.83 \pm 0.1\end{array}$ & $\begin{array}{l}119.6 \pm 3.5 \\
116.6 \pm 6.7\end{array}$ & NS & $\begin{array}{l}5 \\
5\end{array}$ \\
\hline
\end{tabular}

$\overline{\log \mathrm{EC}_{50} \text { indicates logarithm of median effective concentration. } \mathrm{E}_{\max } \text { maximal contractile effect. Global differences }}$ in concentration response curves were compared by two-way ANOVA. Changes in logarithm of median effective concentration $\left(\log \mathrm{EC}_{50}\right.$ ) and maximal contractile responses $\left(\mathrm{E}_{\max }\right)$ between two different groups were analyzed by the Student's $t$-test. NS: not significant. ${ }^{*} p<0.05$ compared to male WT mice. Data are shown as mean \pm S.E.M. 


\subsection{Pulmonary Arterial Relaxation Responses}

The relaxation response produced by methacholine (MCh) was significantly reduced in IPAs of both male and female $C \times 43^{+/-}$mice when compared to WT mice (Figure 4A,B; Table 2). Pharmacological inhibition of $\mathrm{Cx} 43$ with ${ }^{37,43}$ Gap27 also significantly attenuated the relaxation responses produced by MCh in IPAs of both male and female mice (Figure 4C,D; Table 2).

We then confirmed that $\mathrm{MCh}$-induced relaxation responses were dependent upon nitric oxide (NO) since the L-NAME completely inhibited MCh-induced relaxation (Figure 4E; Table 2). Then we assessed the role of $\mathrm{Cx} 43$ in isoprenaline-induced relaxation. Isoprenaline is classically thought to induce relaxation via the CAMP pathway. In these experiments, the relaxation induced by isoprenaline was partially inhibited by ${ }^{37,43}$ Gap27 (Figure 4F; Table 2). Furthermore, we showed nitric oxide plays a role in isoprenaline-induced relaxation since the L-NAME partially attenuated isoprenaline-induced relaxation (Figure 4G; Table 2).

A.

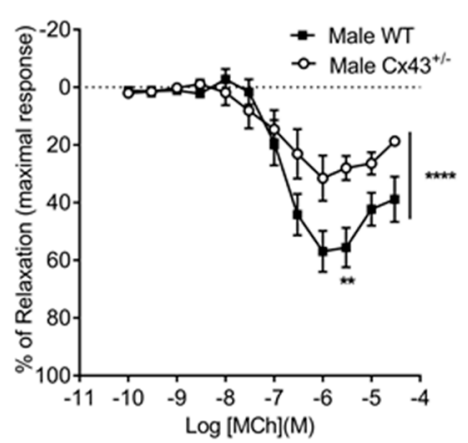

C.

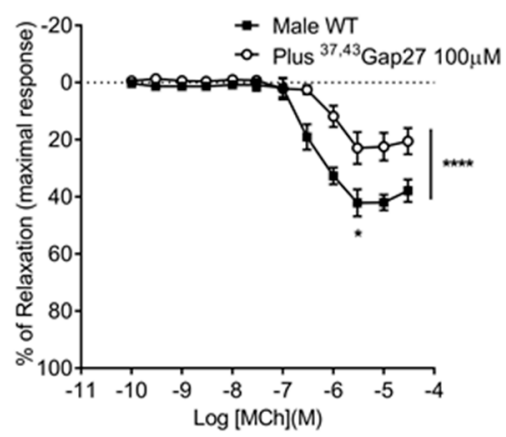

E.

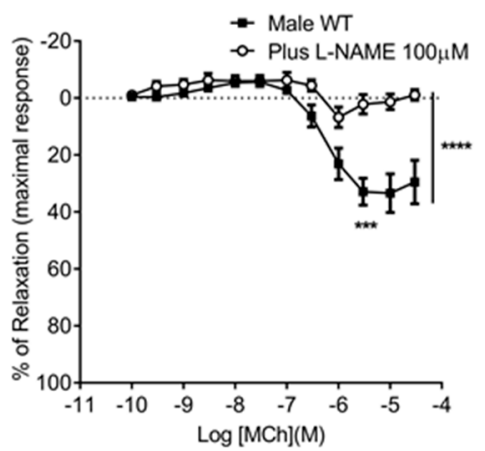

B.

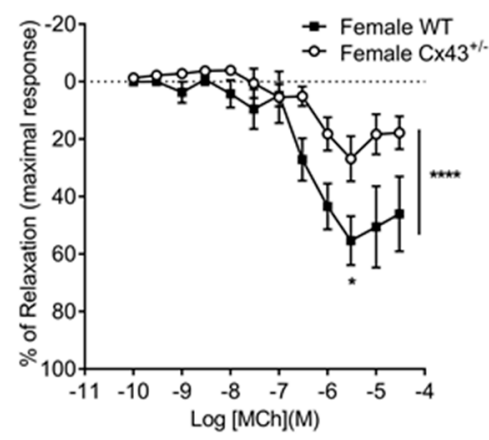

D.

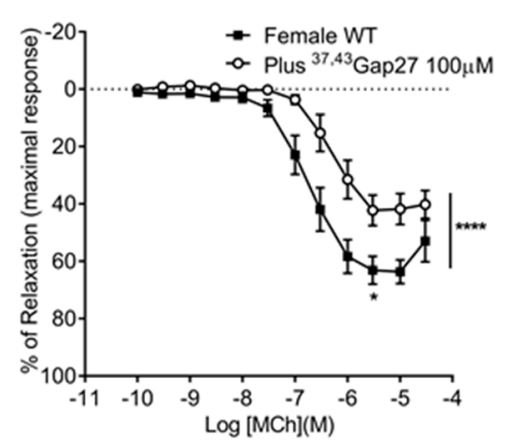

F.

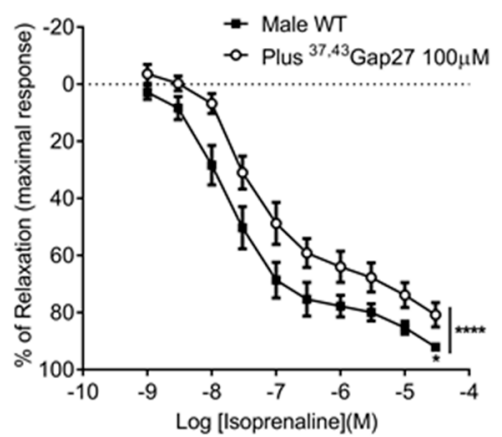

Figure 4. Cont. 
G.

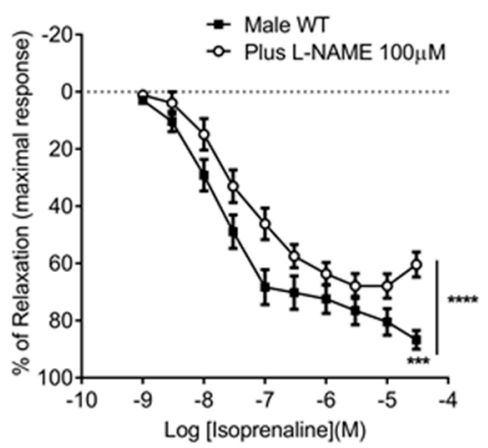

Figure 4. Effects of genetic reduction or pharmacological inhibition of $\mathrm{Cx} 43$ on pulmonary vascular relaxation responses. Male (A) and female (B) $C x 43$ heterozygous $\left(C x 43^{+-}\right)$mice show reduced relaxation in response to $\mathrm{MCh}$. Pre-incubation with ${ }^{37,43}$ Gap27 also reduced the relaxation response in male (C) and female (D) mice. MCh-induced relaxation was ablated in the presence of L-NAME (E). ${ }^{37,43}$ Gap27 partially inhibited isoprenaline-induced relaxation in IPAs from male mice (F) as did L-NAME (G). Global differences in concentration response curves were compared by two-way ANOVA. Changes in logarithm of median effective concentration ( $\log \mathrm{EC}_{50}$ ) and maximal relaxation responses $\left(R_{\max }\right)$ between two different groups were analyzed by using the Student's $t$-test. Data are shown as mean \pm S.E.M. ${ }^{*} p<0.05,{ }^{* *} p<0.01,{ }^{* * *} p<0.001,{ }^{* * * *} p<0.0001, n=5-6$ per group. Statistical symbols shown on the right hand side of graphs indicate global shifts in the concentration response curves. Statistical symbols underneath curves indicate changes in maximal relaxation $\left(R_{\max }\right)$ values.

Table 2. $\log \mathrm{EC}_{50}$ (logarithm of median effective concentration) and $\mathrm{R}_{\max }$ (maximal relaxation) values for MCh-induced or isoprenaline-induced relaxation.

\begin{tabular}{|c|c|c|c|c|c|}
\hline Agonists & Groups & $\log \mathrm{EC}_{50}(\mathrm{M})$ & $R_{\max }(\%)$ & $\begin{array}{c}\text { Global Shift in Concentration } \\
\text { Response Curve }\end{array}$ & $n$ \\
\hline $\mathrm{MCh}$ & $\begin{array}{c}\text { Male WT } \\
\text { Male } C x 43^{+/-}\end{array}$ & $\begin{array}{c}-6.93 \pm 0.08 \\
-7.14 \pm 0.21^{* *}\end{array}$ & $\begin{array}{l}55.6 \pm 6.8 \\
28 \pm 4.1^{* *}\end{array}$ & $* * * *$ & $\begin{array}{l}5 \\
5\end{array}$ \\
\hline $\mathrm{MCh}$ & $\begin{array}{c}\text { Female WT } \\
\text { Female } C x 43^{+-}\end{array}$ & $\begin{array}{l}-6.52 \pm 0.14 \\
-6.48 \pm 0.24\end{array}$ & $\begin{array}{c}55.3 \pm 8.5 \\
26.8 \pm 7.8^{*}\end{array}$ & $* * * *$ & $\begin{array}{l}6 \\
6\end{array}$ \\
\hline $\mathrm{MCh}$ & $\begin{array}{c}\text { Male WT } \\
\text { Plus }{ }^{37,43} \text { Gap27 }\end{array}$ & $\begin{aligned}-6.39 & \pm 0.2 \\
-6.08 & \pm 0.1^{* * * *}\end{aligned}$ & $\begin{array}{c}42.1 \pm 4.6 \\
22.9 \pm 5.6^{*}\end{array}$ & $* * * *$ & $\begin{array}{l}6 \\
6\end{array}$ \\
\hline $\mathrm{MCh}$ & $\begin{array}{c}\text { Female WT } \\
\text { Plus }{ }^{37,43} \text { Gap27 }\end{array}$ & $\begin{aligned}-6.8 & \pm 0.08 \\
-6.36 & \pm 0.1^{* *}\end{aligned}$ & $\begin{array}{c}63.1 \pm 4.8 \\
42.2 \pm 5.2 *\end{array}$ & $* * * *$ & $\begin{array}{l}6 \\
6\end{array}$ \\
\hline $\mathrm{MCh}$ & $\begin{array}{c}\text { Male WT } \\
\text { Plus L-NAME }\end{array}$ & $\begin{array}{c}-6.27 \pm 0.11 \\
\text { not applicable }\end{array}$ & $\begin{array}{c}32.8 \pm 4.6 \\
2.2 \pm 3.4^{* * *}\end{array}$ & $* * * *$ & $\begin{array}{l}6 \\
6\end{array}$ \\
\hline Isoprenaline & $\begin{array}{c}\text { Male WT } \\
\text { Plus }{ }^{37,43} \text { Gap27 }\end{array}$ & $\begin{array}{l}-7.77 \pm 0.17 \\
-7.41 \pm 0.16\end{array}$ & $\begin{array}{l}92.1 \pm 1.19 \\
80.8 \pm 4.2^{*}\end{array}$ & $* * * *$ & $\begin{array}{l}5 \\
5\end{array}$ \\
\hline Isoprenaline & $\begin{array}{c}\text { Male WT } \\
\text { Plus L-NAME }\end{array}$ & $\begin{array}{l}-7.84 \pm 0.2 \\
-7.5 \pm 0.13\end{array}$ & $\begin{array}{c}86.7 \pm 3.2 \\
60.4 \pm 4.3^{* * *}\end{array}$ & $* * * *$ & $\begin{array}{l}6 \\
6\end{array}$ \\
\hline
\end{tabular}

Global differences in concentration response curves were compared by two-way ANOVA. Changes in logarithm of median effective concentration ( $\log \mathrm{EC}_{50}$ ) and maximal relaxation responses $\left(\mathrm{R}_{\max }\right)$ between two different groups were analyzed by using the Student's $t$-test. Data are shown as mean \pm S.E.M. ${ }^{*} p<0.05,{ }^{* *} p<0.01,{ }^{* * *} p<0.001$ and ${ }^{* * * *} p<0.0001$.

2.4. Gene Expression of Bone Morphogenetic Protein Receptor Type II, Tryptophan Hydroxylase 1, and Endothelial Nitric Oxide Synthase in Pulmonary Arteries from Cx43 Heterozygous Mice

Since $C \times 43^{+/-}$mice displayed dysregulated pulmonary vascular reactivity, gene expression of BMPRII (encoded by BMPR2), eNOS (encoded by NOS3), and Tph-1, mediatorsimportant for regulating pulmonary vascular function, were assessed. Expression of BMPR2, NOS3, and Tph-1 were not significantly altered in either male or female $C x 43^{+/-}$mice compared to WT littermates (Figure 5A-C). 
The expression of NOS3 and BMPR2 were significantly lower in female WT mice when compared to male WT mice (Figure 5A,B).

A: BMPRII

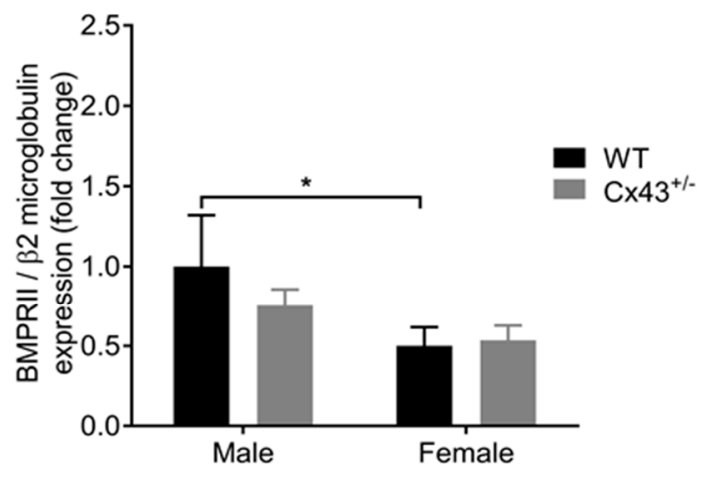

C: Tph1

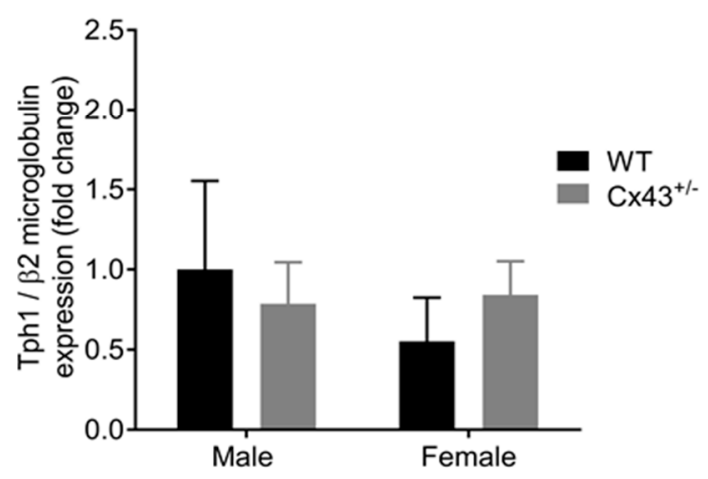

B: eNOS

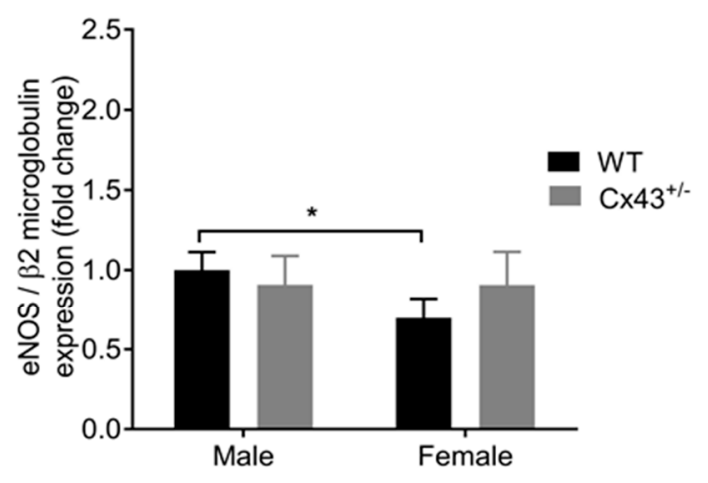

Figure 5. Gene expression of BMPRII (encoded by BMPR2) (A), eNOS (encoded by NOS3) (B), and Tph1 (C) in pulmonary arteries of male and female WT and $C \times 43^{+/-}$mice. No differences were observed in expression of BMPR2, NOS3, or Tph1 between WT and $\mathrm{C} \times 43^{+/-}$mice (either male or female). BMPR2 and NOS3 were significantly downregulated in female WT mice compared to male WTs. Data are presented as mean \pm S.E.M. and were analysed by using two-way ANOVA. ${ }^{*} p<0.05, n=6$ per group with each sample run in triplicate.

\subsection{Effects of Hypoxia on Pulmonary Vascular Contractility in Male Cx43 Heterozugous Mice}

The effects of chronic hypoxia on pulmonary vascular reactivity in $\mathrm{C} x 43^{+/-}$mice were investigated. The hypoxic experiments were carried out in male mice since it has been previously shown that male mice are more susceptible to hypoxic-induced PH than female mice [25]. Both WT and Cx43 mice developed the right ventricular hypertrophy after two weeks of chronic hypoxic exposure, which verifies the mouse hypoxic model (Figure 6A). IPAs derived from chronic hypoxic $\mathrm{C}_{443^{+/}}$mice showed an increased sensitivity to ET-1, which was assessed by a reduced $\mathrm{EC}_{50}$ value and a global leftward shift in the contractile response. In addition, the maximal contractile effect produced by ET-1 was significantly greater in IPAs from hypoxic $\mathrm{C} x 43^{+/-}$mice than from hypoxic WT mice (Figure 6B; Table 3). There was no difference in a contractile response to 5-HT in IPAs from hypoxic $\mathrm{C} x 43^{+/-}$mice (Figure 6C; Table 3). 
A

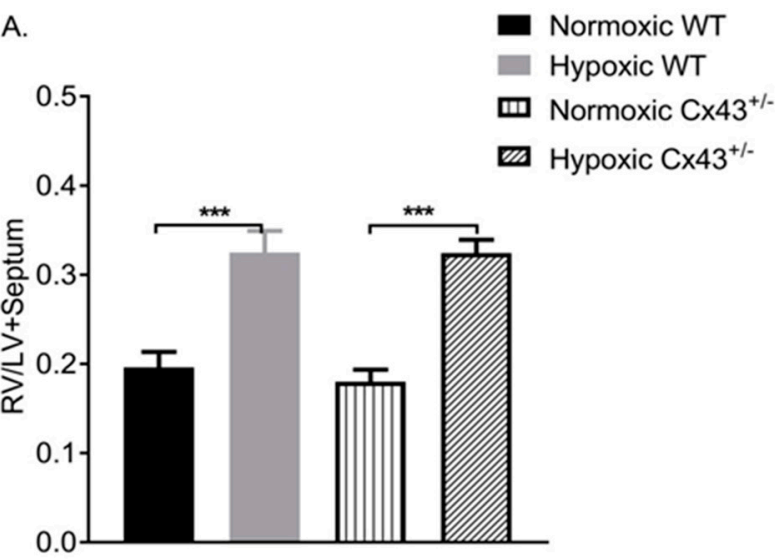

B.

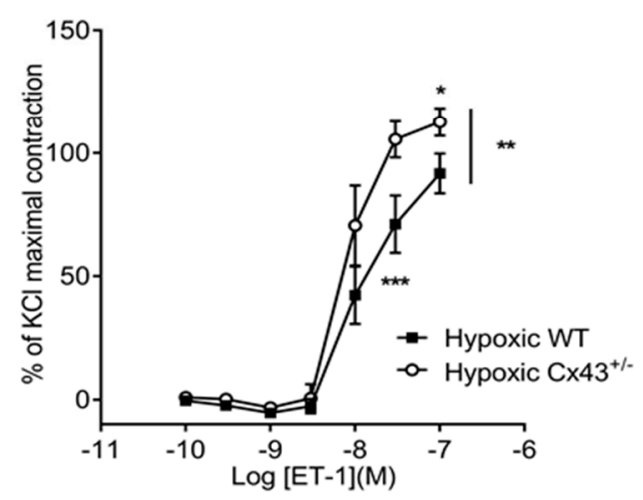

C.

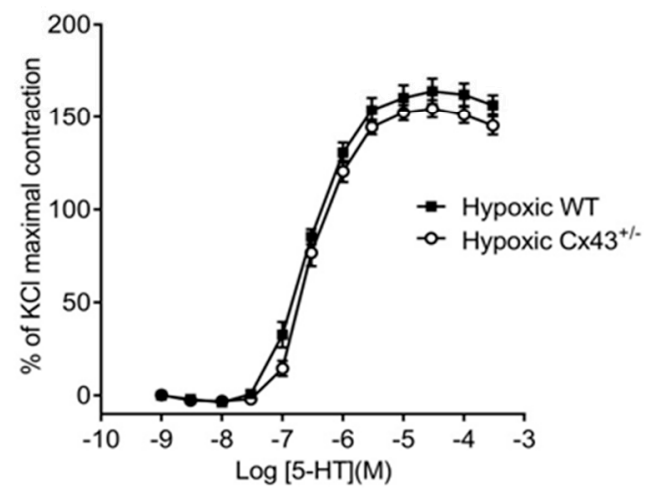

Figure 6. Assessment of the development of right ventricular hypertrophy by right ventricular weight ratio left ventricle plus septal weight (RV/LV+Septum) (A). Concentration response curves (CRCs) to ET-1 (B) and 5-HT (C) in intra-lobar pulmonary arteries derived from hypoxic wildtype (WT) and hypoxic $C x 43$ heterozygous $\left(C \times 43^{+-}\right)$mice. Data are shown as mean \pm S.E.M. Data in panel A were analyzed by two-way ANOVA. In panels B and C, global differences in CRCs were compared by two-way ANOVA. Changes in the logarithm of median effective concentration ( $\log \mathrm{EC}_{50}$ ) and maximal contractile responses $\left(\mathrm{E}_{\max }\right)$ between two different groups were analyzed by using the Student's $t$-test ${ }^{*} p<0.05,{ }^{* *} p<0.01,{ }^{* * *} p<0.001, n=5-7$ per group. The statistical symbol shown on the right hand side of graph B indicates a global shift in the CRC. The symbol underneath the curve indicates changes in the median effective concentration $\left(\mathrm{EC}_{50}\right)$ while the symbol above the curve indicates changes in the maximal response $\left(\mathrm{E}_{\max }\right)$.

Table 3. The contractile effects of ET-1 and 5-HT in intra-lobar pulmonary arteries of hypoxic wildtype and $C x 43$ heterozygous mice.

\begin{tabular}{|c|c|c|c|c|c|}
\hline Agonists & Genotypes & $\log \mathrm{EC}_{50}(\mathrm{M})$ & $E_{\max }(\%)$ & $\begin{array}{c}\text { Global Shift in Concentration } \\
\text { Response Curve }\end{array}$ & $n$ \\
\hline \multirow{2}{*}{ ET-1 } & Hypoxic WT & \multirow{2}{*}{$\begin{array}{c}-7.95 \pm 0.06 \\
-8.07 \pm 0.09 \\
* * *\end{array}$} & $91.7 \pm 8.1$ & \multirow{2}{*}{$* *$} & 6 \\
\hline & Hypoxic $C x 43^{+/-}$ & & $112.7 \pm 5.6^{*}$ & & 7 \\
\hline \multirow{2}{*}{ 5-HT } & Hypoxic WT & $-6.56 \pm 0.04$ & $126 \pm 2.2$ & \multirow{2}{*}{ NS } & 7 \\
\hline & Hypoxic C $x 43^{+/-}$ & $-6.5 \pm 0.03$ & $130.3 \pm 4.5$ & & 7 \\
\hline
\end{tabular}

$\log \mathrm{EC}_{50}$ indicates the logarithm of median effective concentration, $\mathrm{E}_{\max }$ maximal contractile effect. Global differences in concentration response curves were compared by using two-way ANOVA. Changes in logarithm of median effective concentration $\left(\log \mathrm{EC}_{50}\right)$ and maximal contractile responses $\left(\mathrm{E}_{\max }\right)$ between two different groups were analyzed by using the Student's $t$-test. NS: not significant ${ }^{*} p<0.05,{ }^{* *} p<0.01,{ }^{* * *} p<0.001$. Data are shown as mean \pm S.E.M. 


\subsection{Effects of Hypoxia on Expression of Cx43 in Mouse Lung and Pulmonary Artery}

Afterward, the effects of chronic hypoxia on $\mathrm{Cx} 43$ gene and protein expression were assessed. Using qPCR, it was shown that hypoxia significantly down-regulated $C \times 43$ gene expression in both WT and $\mathrm{C}_{4} 3^{+/-}$male mice (Figure 7A). We then used immunofluorescence to visualize the effects of hypoxia on $\mathrm{Cx} 43$ protein expression. Lung expression of $\mathrm{Cx} 43$ (green fluorescence) was reduced in hypoxic WT mice when compared to normoxic WT mice (Figure 7B). Furthermore, Cx43 immunoreactivity was further reduced in lungs of hypoxic $C \times 43^{+/-}$mice when compared to normoxic $\mathrm{C} x 43^{+/-}$mice (Figure 7B).

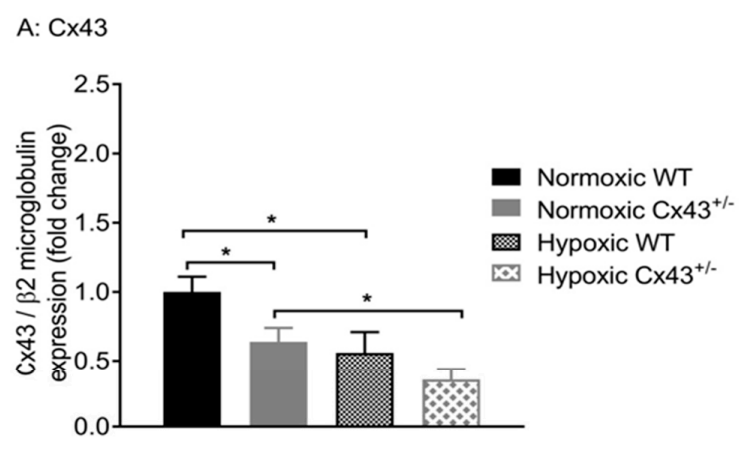

B.

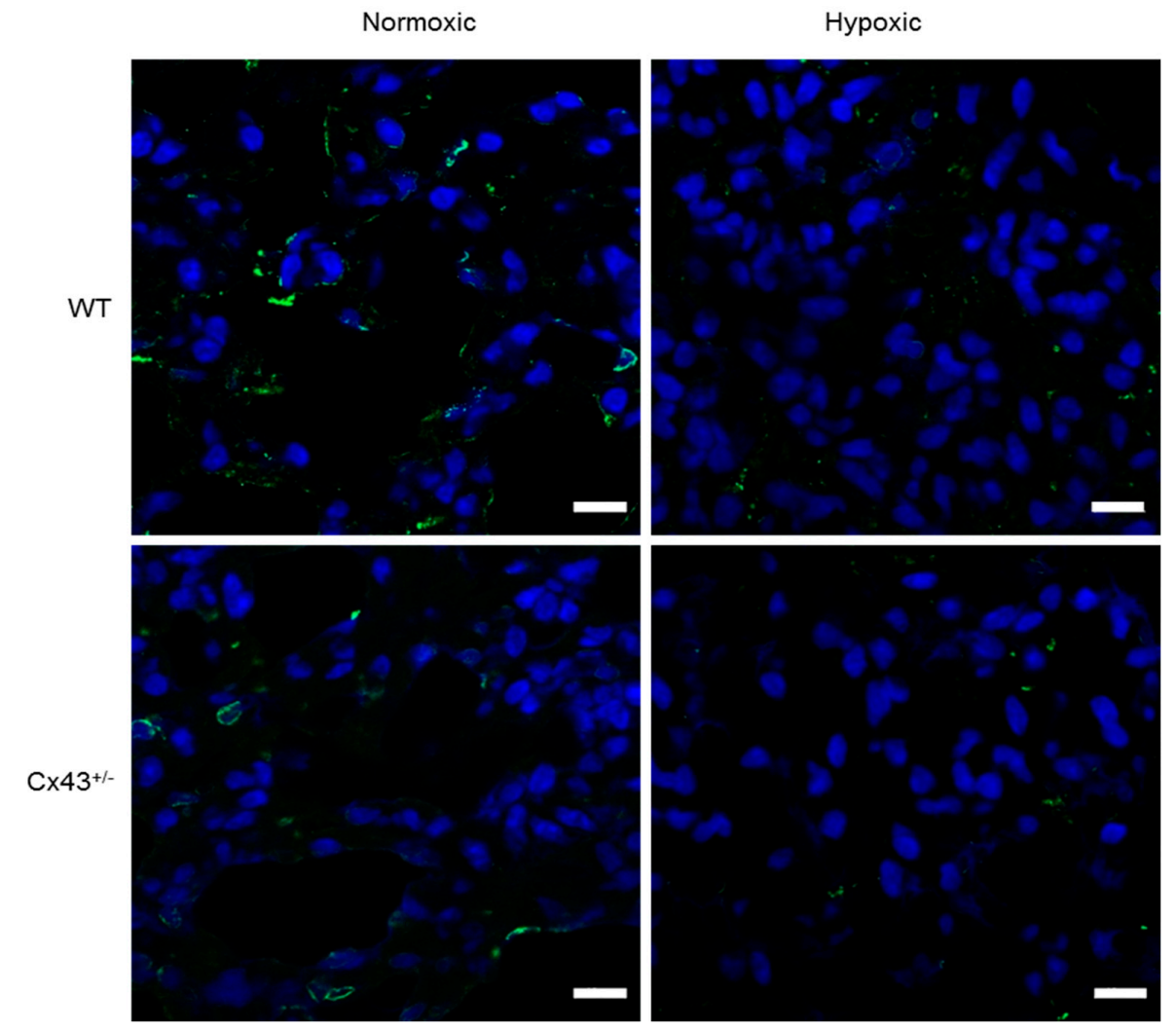

Figure 7. Cx43 expression in pulmonary arteries of wildtype (WT) and Cx43 heterozygous $\left(C \times 43^{+/-}\right)$ mice under normoxic and chronic hypoxic conditions. $C x 43$ gene expression is reduced by hypoxia in both WT and $\mathrm{C} x 43^{+/-}$mice (A). Confocal images of Cx43 immunofluorescence staining in normoxic and hypoxic WT and $\mathrm{C} x 43^{+/-}$mouse lung tissue sections are shown in (B). Green fluorescence punctate findings represent $\mathrm{C} \times 43$ immunoreactivity and blue staining represents nuclei. Scale bars represent $10 \mu \mathrm{m}$. For panel A, data is presented as mean \pm S.E.M. and was analyzed by two-way ANOVA, * $p<0.05, n=6$ with each sample run in triplicate. 


\subsection{Effects of Hypoxia on Gene Expression in Pulmonary Arteries Derived from WT and Cx43 ${ }^{+/-}$Mice}

As chronic hypoxia mediated increased vascular reactivity to ET- 1 and decreased Cx43 expression, the effects of chronic hypoxia on the expression of other vascular connexins and Panx1 were assessed (Figure $8 \mathrm{~A}-\mathrm{D}$ ). Hypoxia mediated a downregulation of $C \times 40$ gene expression in WT mice (Figure 8B) while gene expression of $C x 45$ was up-regulated by hypoxia in $C x 43^{+/-}$mice (Figure $8 C$ ). Hypoxia had no effect on the expression of $C x 37$ or Panx1 in WT or $C x 43^{+/-}$mice (Figure 8A,D).

Gene expression of BMPR2, Tph1, and NOS3 in response to hypoxia in $C \times 43^{+/-}$mice was also assessed. BMPR2 was downregulated by hypoxia in WT mice and Tph1 was up-regulated by hypoxia in $C x 43^{+/-}$mice. There were no differences in BMPR2, NOS3, or Tph1 expression between hypoxic WT and hypoxic $C \times 43^{+/-}$mice (Figure $8 \mathrm{E}-\mathrm{G}$ ).
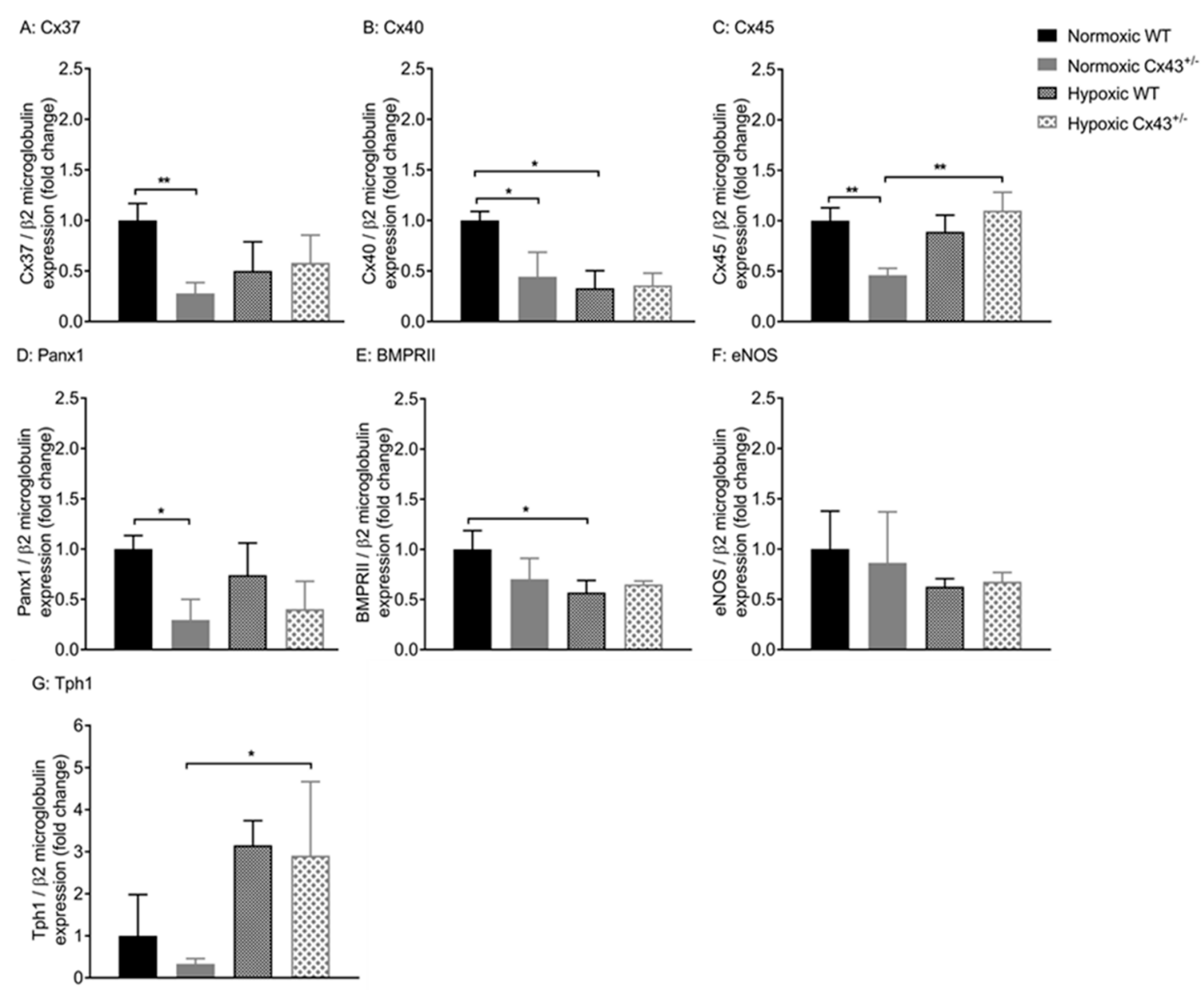

Figure 8. Gene expression of $C x 37$ (A), C $x 40$ (B), C $x 45$ (C), Panx1 (D), BMPRII (E), eNOS (F) and Tph1 (G) in pulmonary arteries of wildtype (WT) and $C \times 43$ heterozygous $\left(C \times 43^{+/-}\right)$mice under normoxic and chronic hypoxic conditions. All data are presented as mean \pm S.E.M. and were analyzed by two-way ANOVA. ${ }^{*} p<0.05,{ }^{* *} p<0.01, n=6$ per group with each sample run in triplicate.

\section{Discussion}

To our knowledge, this is the first study to show that mice genetically deficient in Cx43 develop pulmonary vascular dysfunction. It is also the first study to show that $\mathrm{Cx} 43$ plays a role in NO-induced pulmonary vascular relaxation. These findings add to the growing body of evidence that suggests that $\mathrm{Cx} 43$ is involved in regulation of the pulmonary vasculature. Since PAH is associated with altered pulmonary vascular reactivity, these data suggest $C \times 43$ is worthy of further investigation as a novel therapeutic target for PAH. 
Relaxation responses to MCh were reduced in IPAs from both male and female $\mathrm{C} \times 43^{+/-}$ mice. Subsequently, we found that pharmacological inhibition of Cx43 using ${ }^{37,43}$ Gap27 also attenuated MCh-induced relaxation. ${ }^{37,43}$ Gap 27 inhibits both $\mathrm{Cx} 37$ and $\mathrm{Cx} 43$ and both $\mathrm{C} \times 37$ and $\mathrm{C} \times 43$ are down-regulated in male $\mathrm{C} \times 43^{+/-}$mice. However, the vascular connexins of only $\mathrm{C} \times 43$ are downregulated in female $\mathrm{C} \times 43^{+/-}$mice. Therefore, reduction of MCh-induced relaxation in female $\mathrm{C} \times 43^{+/-}$mice suggests an important role for $\mathrm{Cx} 43$ in this effect. Our studies confirmed that MCh-induced relaxation was NO-dependent since the MCh mediated relaxation responses were completely abolished in the presence of L-NAME. It is widely considered that NO can diffuse through the endothelial and smooth muscle cell membranes to activate guanylate cyclase within the smooth muscle cell and mediate vasodilation. It has been shown, however, that diffusion of NO across the vascular cell membrane requires specific connexin channels [28]. NO opened and permeated hemichannels expressed in HeLa cells transfected and selected to express Cx43, Cx40, or Cx37. In addition, the blockade of connexin channels abolished myoendothelial NO transfer and NO-dependent vasodilation induced by acetylcholine in rat mesenteric arteries [28]. There is also mounting evidence that $\mathrm{NO}$ can interact with gap junctions in a complex and inter-dependent fashion [29]. Cx43 is constitutively S-nitrosylated at cysteine 271 by NO at the myoendothelial gap junctions. This nitrosylation keeps the myoendothelial gap junction open and denitrosylation closes the gap junction channel [30]. Additionally, NO has been shown to enhance gap junction coupling and increase trafficking of $\mathrm{C} \times 40$ to the membrane in endothelial cells via the protein kinase A activation [31]. $\mathrm{C} \times 40$ has been shown to co-localize with eNOS in the mouse aorta and is involved in conducting vasodilation [32]. $\mathrm{C} x 40$ knock out $\left({\left.\mathrm{C} x 40^{-/}\right)}^{-}\right.$mice showed reduced basal and acetycholine induced NO release and reduced eNOS expression in aortas [32]. However, $\mathrm{NO}$ can act as a negative regulator of Cx37, which reduces Cx37-mediated dye transfer and electrical coupling in human umbilical vascular endothelial cells (HUVEC) and mouse microvascular endothelial cells [33,34]. Therefore, it is possible that $\mathrm{C} \times 43$ and $\mathrm{NO}$ interact in such a fashion that when $\mathrm{C} \times 43$ is genetically downregulated or pharmacologically inhibited, it leads to a reduction in NO-mediated vasorelaxation. In the present study, pulmonary arterial gene expression of $e N O S$ was unchanged in male and female $C \times 43^{+/-}$mice when compared to WT controls. It would, however, be of interest to investigate eNOS protein levels and also MCh-induced NO release in pulmonary arteries from WT and $C \times 43^{+/-}$mice. It would also be of interest to investigate potential interactions between eNOS and $\mathrm{Cx} 43$ using co-immunoprecipitation.

${ }^{37,43} \mathrm{Gap} 27$ also mediated a small but significant inhibition of isoprenaline-induced relaxation. Isoprenaline is classically thought to act through the cAMP pathway. In the present study, isoprenaline-induced relaxation was, however, partially inhibited by L-NAME, which suggests that NO plays a role in isoprenaline-induced relaxation. A previous study has also shown $\beta_{2}$ adrenoceptor induced relaxation in mouse pulmonary arteries are attenuated by the L-NAME, endothelial denudation, or deletion of $e$ NOS [35]. $\beta_{2}$ adrenoceptors have been detected in the mouse pulmonary endothelial layer by immunostaining [35]. The inhibitions of isoprenaline relaxation mediated by ${ }^{37,43}$ Gap27 and L-NAME were of a similar magnitude. It is, therefore, possible that inhibition of connexin mediated communication via ${ }^{37,43}$ Gap27 inhibits the NO component of isoprenaline relaxation. In future studies, it would be of interest to analyze whether smooth muscle responses to NO are affected by downregulation of Cx43. This could be achieved using an NO donor such as sodium nitroprusside.

Enhanced ET-1 mediated contraction was observed in IPAs derived from both normoxic and hypoxic male $C x 43^{+/-}$mice compared to their WT counterparts. Normoxic female $C x 43^{+/-}$mice did not show an increased contractile response to ET-1. However, male $C \times 43^{+/-}$mice showed downregulation of $C x 37, C x 40, C x 45$, and Panx1. These effects were not observed in female $C \times 43^{+/-}$ mice. Downregulation of $C x 37, C x 40, C x 45$, or Panx1 may, therefore, play a role in the increased contractile response to ET-1 observed in the male $\mathrm{C} x 43^{+/-}$mice. The reduced Cx43 expression observed in the pulmonary arteries of male mice compared to female mice observed in this study may also contribute to the increased effects of ET- 1 in male $C x 43^{+/-}$mice. Gender differences in the 
endothelin system may also contribute to contractile differences between male and female $C \times 43^{+/-}$ mice [36]. Studies have shown that plasma endothelin levels were higher in men when compared to women [37,38]. At the receptor level, the ratio of $\mathrm{ET}_{\mathrm{A}}$ and $\mathrm{ET}_{\mathrm{B}}$ receptors in the endothelium of saphenous vein was greater in male subjects (3:1) than in female subjects (1:1) [39]. Haemodynamically, a rat model showed pressor responses induced by intravenous administration of ET- 1 were greater in male rats than in female rats [40]. In vitro cell culture studies have also confirmed that 17- $\beta$ oestradiol (E2) inhibited ET-1 gene expression through the extracellular signal regulated kinase (ERK) pathway [41].

5-HT mediated contractile responses in the IPAs were not affected by the partial loss of $C x 43$ in either male or female mice under either normoxic or hypoxic conditions. Therefore, the effects of reduced $C \times 43$ gene expression varied according to the agonist used. These results agree with previously published data showing that the effects of pharmacological inhibition by ${ }^{37,43} \mathrm{Gap} 27$ on contractile responses in IPAs were dependent on the agonist used [18]. In line with the current results, Billaud et al. showed that ${ }^{37,43}$ Gap27 had no effect on 5-HT induced contraction in IPAs derived from hypoxic rats. However, they did report that ${ }^{37,43}$ Gap27 could inhibit 5-HT induced contraction in IPAs from normoxic rats. In contrast with the results reported here showing that downregulation of $C x 43$ enhanced ET-1 mediated contraction in IPAs form both normoxic and hypoxic $C \times 43^{+/-}$mice, Billaud et al. found that ${ }^{37,43}$ Gap27 had no effect on ET-1 induced contraction in IPAs derived from normoxic or hypoxic rats [18]. 5-HT and ET-1 have different mechanisms of contraction. Since connexins are modulated by PKA, PKC, and calcium [42], the role of connexin mediated communication in the contractile response differs according to the agonist used. A possible reason for the disparity between the Billaud study and our own could be due to the ratiometric changes in the balance of $\mathrm{Cx} 43: \mathrm{Cx} 40: \mathrm{Cx} 37$ expression between rats and mice. A number of studies have reported tissue and species specific variation in connexin expression profiles and ${ }^{37,43} \mathrm{Gap} 27$ is defined as being specific to the SRPTEKTIFII sequence-conserved between $C \times 43$ and $C \times 37$ but different in Cx40 [43-46]. In addition, $C \times 43^{+/-}$ mice will have compensatory changes in other genes, which may affect the contractile response while ${ }^{37,43}$ Gap27 inhibits Cx37 as well as Cx43. This also potentially affects the contractile response.

In the gene expression studies, $C \times 43$ expression was higher in female mice than in male mice. This is in keeping with a report which showed that $\mathrm{Cx} 43$ expression was higher in rat cardiomyocytes derived from females than males [47]. Furthermore, treatment with oestradiol increased Cx43 expression in human myometrium [48]. In addition to this, there is direct evidence that estrogen can regulate $C x 43$ gene expression since the promotor region of $C x 43$ gene contains an estrogen response element [49].

Chronic hypoxic rodents are a commonly used model for PAH. In the current study, the chronic hypoxia suppressed Cx43 gene and protein expression are located in the pulmonary arteries of both WT and $C \times 43^{+/-}$mice. Hypoxia can regulate $C x 43$ expression post-translationally by phosphorylation [50]. For example, one study showed exposure to hypoxia is associated with an increase in phosphorylation of Cx43- serine 368 (Ser368) in human microvascular endothelial cells and this phosphorylation was associated with downregulation Cx43 protein expression [51]. As hypoxia downregulates Cx43 expression, it would be of interest in future studies to assess the effects of hypoxia on MCh-induced relaxation in $\mathrm{C} x 43^{+/-}$mice. The current study showed $\mathrm{C} x 40$ expression was also downregulated in hypoxic WT mice. Previous studies have shown that $\mathrm{Cx} 40$ expression was reduced during PAH in rats and treatment with sildenafil increased Cx40 expression via BMP signaling $[52,53]$. We found $C x 45$ expression to be upregulated in the $\mathrm{C} x 43^{+/-}$mice under chronic hypoxic conditions. The function of $\mathrm{C} \times 45$ in the vasculature remains unknown even though it has long been known to be expressed in vascular smooth muscle cells [54].

It is interesting to note that $\mathrm{C} \times 3^{+/-}$mice did not develop increased right ventricular hypertrophy $(\mathrm{RVH})$ in response to hypoxia compared to their wildtype counterparts. It has previously been shown by ourselves and others that changes in pulmonary vascular pressures and pulmonary vascular remodeling do not always lead to the development of RVH in mice. For example, increased 
pulmonary pressures and remodeling have been observed in the absence of RVH in mice that over-express the serotonin transporter, mice that over-express Mts 1, and mice that are dosed with dexfenfluramine [55-57]. In addition, Cx43 is highly expressed in cardiac myocytes and is thought to play an important role in hypertrophy of these cells. Expression and localization of Cx43 in cardiac myocytes has been shown to be dynamically regulated in various animal models of cardiac hypertrophy [58]. Therefore, it is possible that cardiac myocytes from $\mathrm{Cx} 43^{+/-}$mice are functionally abnormal and, therefore, have an atypical hypertrophic response to hypoxia.

Female $C \times 43^{+/-}$mice did not exhibit the compensatory reduction in gene expression of $C \times 37$, $C x 40, C x 45$, or Panx1 that was observed in male $C x 43^{+/-}$mice. Multiple lines of evidence show that $C x 43, C x 40$, and $C x 37$ are interdependent on each other and compensatory changes occur upon connexin deletion. For instance, in $C \times 40$ knock out $\left(C \times 40^{-/-}\right)$mice both total and smooth muscle $C \times 43$ protein expression was reduced in the mouse aortas [59]. In addition, in $C x 40^{-/-}$mice, the pericellular component of $\mathrm{Cx} 43$ staining was lost and there was increased redistribution of $\mathrm{Cx} 43$ in the perinuclear region [59]. This suggests deletion of $C x 40$ not only leads to $C \times 43$ downregulation but also affects its trafficking. Conversely, another group found that $\mathrm{C} x 40^{-/-}$mice showed upregulation of $\mathrm{C} \times 37$ and $\mathrm{Cx} 43$ in the aortic endothelium [60]. In $\mathrm{C} x 40^{-/-}$neonatal mice, $\mathrm{Cx} 37$ protein expression was downregulated in the endothelium and there was an increased Cx37 and Cx43 in the medial layer [61]. Genetic deletion of $C x 37$ in mice showed reduction in endothelial Cx40 [61]. In the present study, we have assessed changes in gene expression in the whole pulmonary artery. It would be of interest to assess cell type specific changes in future studies.

Gene expression of $e N O S, B M P R I I$, or Tph 1 were not affected by the loss of $C x 43$ under normoxic or hypoxic conditions. Among the normoxic WT mice, eNOS and BMPRII expression was reduced in the females compared to male WT mice. The literature on eNOS expression in PAH patients is contradictory. eNOS was initially reported to be decreased in lungs of PAH patients [62], but evidence later found eNOS expression was unchanged or even increased in PAH patients [63,64]. Furthermore, NO levels have been shown to be reduced in PAH patients [65] and it has been reported that the activity of eNOS rather than its expression was altered in a murine model of PAH [63]. Our findings show that BMPRII expression is reduced in pulmonary arteries from female mice, which is in line with proof that activation of the estrogen response element in the promoter region of BMPRII can downregulate BMPRII expression [66].

In conclusion, this study has shown that $\mathrm{Cx} 43$ plays a role in NO-dependent vasodilation in the pulmonary vasculature. $\mathrm{Cx} 43$ is also involved in pulmonary vascular contractility. However, effects on contractility are gender-dependent and agonist-dependent. Hypoxia has been shown to decrease Cx43 expression in mouse pulmonary arteries, which is an effect that may contribute to the increased vasoreactivity observed under hypoxic conditions.

\section{Materials and Methods}

\subsection{Ethical Statement}

All experimental procedures were carried out in accordance with the United Kingdom Animal Procedures Act (1986) and with the "Guide for the Care and Use of Laboratory Animals" published by the US National Institutes of Health (NIH publication no.85, eighth edition). Ethical approval was granted by the Glasgow Caledonian University Animal Welfare and Ethics Committee (PPL70/7875, 16 September 2013).

\subsection{Animals}

Male and female wild-type (WT) and Cx43 heterozygous $\left(C x 43^{+/-}\right)$mice (C57BL6, 5 to 9 months old) were used in this study. The generation of $\mathrm{C} x 43^{+/-}$mice was originally carried out by replacing exon 2 of the $C x 43$ gene with the neomycin resistance gene, which was previously described [24]. 
Mice were grouped under standard laboratory conditions. All mice had access to a commercial diet and water ad libitum.

\subsection{Genotyping}

DNA was extracted from ear notch tissues derived from WT and $C \times 43^{+/-}$mice. Tissues were suspended in $300 \mu \mathrm{L}$ TNES buffer [10 mM tris(hydroxymethyl)aminomethane (Tris), $0.4 \mathrm{M}$ sodium chloride $(\mathrm{NaCl}), 100 \mathrm{mM}$ ethylenediaminetetraacetic acid (EDTA), and $0.6 \%$ sodium dodecyl sulphate (SDS)] to which $1.5 \mu \mathrm{L}$ proteinase K (Fisher Scientific, Loughborough, UK) was added. Samples were then incubated overnight at $55{ }^{\circ} \mathrm{C}$. The next day, $84 \mu \mathrm{L}$ of $5 \mathrm{M} \mathrm{NaCl}$ was added to each sample and samples were centrifuged for $10 \mathrm{~min}$. The supernatant was collected and transferred to fresh tubes. DNA was precipitated by adding $200 \mu \mathrm{L}$ ice cold $100 \%$ ethanol to each tube and vortexing. Samples were then centrifuged for $10 \mathrm{~min}$, the supernatant was discarded, and the pellet was retained. Excess salt was removed by adding $200 \mu \mathrm{L}$ ice cold $75 \%$ ethanol and samples were centrifuged again for $10 \mathrm{~min}$. The supernatant was decanted gently and the pellet was allowed to air dry. The pellet was then re-suspended in $15 \mu \mathrm{L}$ nuclease-free water and stored at $-20^{\circ} \mathrm{C}$ until use. A polymerase chain reaction (PCR) was then carried out to amplify the Cx43 (GJA1) and neomycin resistance $\left(n e o^{r}\right)$ genes. The primers used were as follows: $n e o^{r}$ forward $5^{\prime}$-GATCGGCCATTGAACAAGATG, melting temperature $(\mathrm{Tm})=56.4{ }^{\circ} \mathrm{C}$, molecular weight $(\mathrm{MW})=6808.5, n e 0^{r}$ reverse: $5^{\prime}$-CCTGATGCTCTTCGTCCAGAT Tm $=57.2^{\circ} \mathrm{C}$, $\mathrm{MW}=6637.3, \mathrm{C} x 43$ forward: $5^{\prime}-\mathrm{CAGTCTGCCTTTCGCTGT}, \mathrm{Tm}=56^{\circ} \mathrm{C}, \mathrm{MW}=5433 ; \mathrm{C} x 43$ reverse: $5^{\prime}$-GTAGACCGCACTCAGGCT, $\mathrm{Tm}=58^{\circ} \mathrm{C}, \mathrm{MW}=5485$. All primers were purchased from Integrated DNA technologies, Belgium. PCR reactions were performed in a thermal cycler (MJ Research PTC-100 Thermal Cycler, Watertown, MA, USA) and comprised an initial denaturation at $95{ }^{\circ} \mathrm{C}$ for $3 \mathrm{~min}$ followed by 40 cycles of: denaturation at $95^{\circ} \mathrm{C}$ for $30 \mathrm{~s}$, annealing at $55^{\circ} \mathrm{C}$ for $30 \mathrm{~s}$, and extension at $72{ }^{\circ} \mathrm{C}$ for $1 \mathrm{~min}$. A final extension step was carried out at $72{ }^{\circ} \mathrm{C}$ for $15 \mathrm{~min}$. Samples were then run in $2 \%$ agarose gel $(v / v)$ for $45 \mathrm{~min}$ at $100 \mathrm{~V}$.

\subsection{Induction of Hypoxia}

For induction of hypoxia, male WT and $\mathrm{C} x 43^{+/-}$mice were placed in a hypobaric chamber for 14 days, which is previously described [19]. The pressure was adjusted to $550 \mathrm{mbar}$ (equivalent to $10 \%$ $v / v \mathrm{O}_{2}$ ) slowly over two days to allow mice to acclimate. The temperature was maintained at $20-22{ }^{\circ} \mathrm{C}$. Control littermates were kept in a normoxic environment.

\subsection{Tissue Preparation}

Mice were euthanized by injection of phenobarbitone $(60 \mathrm{mg} / \mathrm{kg}$ i.p.). After death was confirmed, the chest walls were opened using the mediastinal approach and the hearts and lungs were dissected freely.

\subsection{Wire Myography Studies}

Pharmacological experiments were carried out in third generation intra-lobar pulmonary arteries (IPAs; $300 \mu \mathrm{m}$ internal diameter), which was previously described $[67,68]$. IPAs were mounted on a wire myograph (Danish Myo Technology, DMT) in freshly prepared Krebs-Henseleit Solution (composition (mmol/L) $\mathrm{NaCl} 119, \mathrm{KCl} 4.7, \mathrm{CaCl}_{2} 2.5, \mathrm{MgSO}_{4}$ 1.2, $\mathrm{NaHCO}_{3} 25, \mathrm{KH}_{2} \mathrm{PO}_{4} 1.2$, and D-glucose 5.5) at $\left(37{ }^{\circ} \mathrm{C}\right)$ and gassed with $95 \% \mathrm{O}_{2} / 5 \% \mathrm{CO}_{2}$. All chemicals required for Krebs-Henseleit solution were purchased from Fisher Scientific except $\mathrm{CaCl}_{2}$ which was purchased from VWR International Ltd. (Lutterworth, Leicestershire, UK). Following equilibration for one hour, IPAs from normoxic mice were placed under pressures of $12-15 \mathrm{mmHg}$ and IPAs from hypoxic mice that were placed under pressures of 30-35 $\mathrm{mmHg}$ to mimic the in vivo environment described previously [67]. Arteries were initially constricted with potassium chloride $(\mathrm{KCl}, 60 \mathrm{mM})$, which were then washed out. These processes were repeated two times before contractile or relaxation experiments 
were carried out. For contractile experiments, cumulative concentration response curves (CCRCs) to 5-HT $(1 \mathrm{nM}-300 \mu \mathrm{M})$ or ET-1 $(0.1 \mathrm{nM}-0.1 \mu \mathrm{M})$ were constructed. For relaxation experiments, vessels were pre-constricted with phenylephrine $(\mathrm{PE} ; 3 \mu \mathrm{M})$ and $\mathrm{CRC}$ to $\mathrm{MCh}(0.1 \mathrm{nM}-30 \mu \mathrm{M})$ or isoprenaline $(1 \mathrm{nM}-30 \mu \mathrm{M})$ were constructed. In a subset of relaxation experiments, vessels were incubated with ${ }^{37,43} \mathrm{Gap} 27(100 \mu \mathrm{M})$ for $30 \mathrm{~min}$ prior to $\mathrm{MCh}$ or isoprenaline-induced relaxation responses. ${ }^{37,43} \mathrm{Gap} 27$ has previously been shown to have an $\mathrm{IC}_{50}$ of $31.5 \pm 4.1 \mu \mathrm{M}$ and to produce a maximum effect at $100 \mu \mathrm{M}$ [69]. We previously used ${ }^{37,43} \mathrm{Gap} 27$ at $100 \mu \mathrm{M}$ [70-72]. In another subset of relaxation experiments, the L-NAME $(100 \mu \mathrm{M})$ was used to inhibit eNOS. In these experiments the L-NAME was applied for $30 \mathrm{~min}$ prior to pre-constriction with PE and the concentration of PE was reduced to $30 \mathrm{nM}$. It should be noted that $30 \mathrm{nM}$ PE in the presence of L-NAME produced a similar contractile response to $3 \mu \mathrm{M}$ PE alone. Changes in isometric tension were recorded on LabChart 7 software (AD Instruments Pty Ltd., Bella Vista, New South Wales, Australia). PE, L-NAME, MCh, ET and 5-HT were purchased from Sigma-Aldrich Company Ltd. (Gillingham, Dorset, UK).

\subsection{Quantitative Real Time PCR ( $q P C R$ )}

Main and branch pulmonary arteries (1st and 2nd order) were homogenized and RNA was extracted using the Nucleospin RNA kit (MACHEREY-NAGEL GmbH \& Co. KG, Düren, Germany) as per the manufacturer instructions. RNA was then reverse transcribed to cDNA using the Precision nanoScript ${ }^{\mathrm{TM}} 2$ Reverse Transcription Kit (Primerdesign Ltd., Chandler's Ford, UK), according to the manufacturer's protocols. qPCR was performed using Precision PLUS $2 x$ qPCR master mix (Primerdesign Ltd.) II with taqman primers described in Table 4. $\beta_{2}$-microglobulin (B2M) (assay ID: HK-DD-mo-300, Primerdesign Ltd.) was used as the endogenous control and the sequences for the B2M were kept confidential by Primerdesign Ltd.

qPCR reactions were run in a real time PCR thermo-cycler machine (Viia ${ }^{\mathrm{TM}} 7$ Real Time PCR System, ThermoFisher Scientific, Loughborough, UK) using the following conditions: $50^{\circ} \mathrm{C}$ for $2 \mathrm{~min}$ and $95^{\circ} \mathrm{C}$ for $10 \mathrm{~min}$ followed by 40 cycles of $95^{\circ} \mathrm{C}$ for $15 \mathrm{~s}$ and $60^{\circ} \mathrm{C}$ for $1 \mathrm{~min}$. Gene expression was analyzed by the $2^{\Delta \Delta C t}$ method. Samples from at least six mice were used for each group and reactions for each sample were run in triplicate.

Table 4. TaqMan probe primers and their sequences for qPCR reactions.

\begin{tabular}{cccc}
\hline Gene & Sequence & Product Length (Base Pairs) & Tm $\left({ }^{\circ} \mathbf{C}\right)$ \\
\hline $\begin{array}{c}\text { GJA1 } \\
(\text { C } 43)\end{array}$ & $\begin{array}{c}\text { Sense-ACTGAGCCCATCCAAAGACT } \\
\text { Antisense-CAGGAGGAGACATAGGTGAGAG }\end{array}$ & 95 & $\begin{array}{c}\text { Sense-56.6 } \\
\text { Antisense-57.3 }\end{array}$ \\
\hline $\begin{array}{c}\text { GJA5 } \\
(\text { Cx40 })\end{array}$ & $\begin{array}{c}\text { Sense-ATGGTATACTCTCCTCAGCACTAC } \\
\text { Antisense-CCAGTCATTGAGAAGACTCAGAAC }\end{array}$ & 117 & $\begin{array}{c}\text { Sense-56.8 } \\
\text { Antisense-57 }\end{array}$ \\
\hline $\begin{array}{c}\text { GJA4 } \\
(\text { Cx37 })\end{array}$ & $\begin{array}{c}\text { Sense-ACACCCACCCTGATCTACCT } \\
\text { Antisense-TCCCTCTTTCTGCCGCAAC }\end{array}$ & 75 & $\begin{array}{c}\text { Sense-57.5 } \\
\text { Antisense-58 }\end{array}$ \\
\hline $\begin{array}{c}\text { GJC1 } \\
(\text { Cx45 })\end{array}$ & $\begin{array}{c}\text { Sense-CAGAGATGGAGTTAGAAAGCGAAA } \\
\text { Antisense-AAGCCCACCTCAAACACAGT }\end{array}$ & 148 & $\begin{array}{c}\text { Sense-57.8 } \\
\text { Antisense-57.7 }\end{array}$ \\
\hline Panx 1 & $\begin{array}{c}\text { Sense-TCAGCCTCATTAACCTCATTGTG } \\
\text { Antisense-TGGGCAGGATTTCATACACTTTG }\end{array}$ & 114 & $\begin{array}{c}\text { Sense-57.5 } \\
\text { Antisense-58 }\end{array}$ \\
\hline $\begin{array}{c}\text { NOS3 } \\
(\mathrm{eNOS})\end{array}$ & $\begin{array}{c}\text { Sense-GGAAGTAGCCAATGCAGTGAA } \\
\text { Antisense-GCCAGTCTCAGAGCCATACA }\end{array}$ & 97 & $\begin{array}{c}\text { Sense-56.8 } \\
\text { Antisense-57.2 }\end{array}$ \\
\hline $\begin{array}{c}\text { BMPR2 } \\
(B M P R I I)\end{array}$ & $\begin{array}{c}\text { Sense-TGTTATCAGTGACTTTGGTTTATCC } \\
\text { Antisense-CTTATAGCCCGCATTATCTTCTTCC }\end{array}$ & 84 & $\begin{array}{c}\text { Sense-56.5 } \\
\text { Antisense-56.3 }\end{array}$ \\
\hline Tph1 & $\begin{array}{c}\text { Sense-AATTCACGGAAGAAGAGATTAAGAC } \\
\text { Antisense-CCAGTTGCGGGATGTTGTC }\end{array}$ & 150 & $\begin{array}{c}\text { Sense-56.3 } \\
\text { Antisense-56.9 }\end{array}$ \\
\hline
\end{tabular}

\subsection{Immunofluorescence Staining}

Sagittal sections $(7 \mu \mathrm{M})$ were cut from lung embedded at an optimal cutting temperature (OCT) compound using a cryostat (Cryostar ${ }^{\mathrm{TM}}$ NX70 Cryostat from, Thermofisher Scientific). Sections were 
fixed in ice cold $\left(-20^{\circ} \mathrm{C}\right)$ methanol for $20 \mathrm{~min}$ and rehydrated in phosphate buffer saline (PBS, $\left.\mathrm{pH}=7.4\right)$. Sections were permeablised in PBS containing $0.1 \%(v / v)$ Triton-X100 before being blocked in $5 \%(w / v)$ skimmed milk in PBS solution for $30 \mathrm{~min}$ at room temperature. Sections were stained with primary antibody (rabbit polyclonal anti-Cx43, 1:100; Sigma-Aldrich Company Ltd., Gillingham, Dorset, UK) and incubated at $4{ }^{\circ} \mathrm{C}$ overnight. The next day, sections were washed in PBS for $30 \mathrm{~min}$ at room temperature and incubated with secondary antibody (goat anti-rabbit conjugated to Alexa flour 488, 1:500; Fisher Scientific) at $4{ }^{\circ} \mathrm{C}$ for $2 \mathrm{~h}$. Nuclei were counter-stained with DAPI (1:1000; Thermofisher. Loughborough, UK). Mounting medium was applied on tissue sections and cover slides were applied. Slides were then examined under the LSM 800 Carl ZEISS confocal microscope, (Königsallee, Germany) for immunoreactivity.

\subsection{Statistical Analysis}

All data were shown as mean \pm S.E.M. Data for cumulative concentration response curves (CRCs) were analyzed using GraphPad Prism 6 software (La Jolla, CA, USA). Data were fitted to a logistic equation, $\mathrm{CRCs}$ were generated, and $\mathrm{EC}_{50}$ values were derived. Global differences in CRCs were compared by two-way ANOVA with the Bonferroni's post hoc test. Changes in the logarithm of median effective concentration ( $\log \mathrm{EC}_{50}$ ), maximal contractile responses $\left(\mathrm{E}_{\max }\right)$, and maximal relaxation responses $\left(R_{\max }\right)$ between two different groups were analyzed by using the Student's $t$-test.

Author Contributions: Y.D., P.E.M., and J.E.N. conceived and designed the experiments. M.H. contributed to the design of experiments, performed the experiments, and analyzed the data. A.S. and B.E.F. contributed to myography experiments. M.H. and Y.D. wrote the manuscript with input from J.E.N. and P.E.M.

Acknowledgments: We would like to thank. Bjarne Due Larsen (Zealand Pharma) for supplying ${ }^{37,43}$ Gap27 peptide as a kind gift. We would also like to thank Angus M Shaw for his advice on the myography experiments. This work was funded by grants from the British Pharmacological Society and Tenovus Scotland awarded to Yvonne Dempsie and Patricia Martin.

Conflicts of Interest: The authors declare no conflict of interest.

\section{References}

1. Hoeper, M.M.; Bogaard, H.J.; Condliffe, R.; Frantz, R.; Khanna, D.; Kurzyna, M.; Langleben, D.; Manes, A.; Satoh, T.; Torres, F. Definitions and Diagnosis of Pulmonary Hypertension. J. Am. Coll. Cardiol. 2013, 62, D42-D50. [CrossRef] [PubMed]

2. Benza, R.L.; Miller, D.P.; Barst, R.J.; Badesch, D.B.; Frost, A.E.; McGoon, M.D. An Evaluation of Long-Term Survival from Time of Diagnosis in Pulmonary Arterial Hypertension from the REVEAL Registry. Chest 2012, 142, 448-456. [CrossRef] [PubMed]

3. Dempsie, Y.; MacLean, M.R. The Influence of Gender on the Development of Pulmonary Arterial Hypertension. Exp. Physiol. 2013, 98, 1257-1261. [CrossRef] [PubMed]

4. Dempsie, Y.; Martin, P.; Upton, P.D. Connexin-Mediated Regulation of the Pulmonary Vasculature. Biochem. Soc. Trans. 2015, 43, 524-529. [CrossRef] [PubMed]

5. Eddahibi, S.; Guignabert, C.; Barlier-Mur, A.M.; Dewachter, L.; Fadel, E.; Dartevelle, P.; Humbert, M.; Simonneau, G.; Hanoun, N.; Saurini, F.; et al. Cross Talk between Endothelial and Smooth Muscle Cells in Pulmonary Hypertension: Critical Role for Serotonin-Induced Smooth Muscle Hyperplasia. Circulation 2006, 113, 1857-1864. [CrossRef] [PubMed]

6. MacLean, M.R.; Dempsie, Y. The serotonin hypothesis of pulmonary hypertension revisited. In Membrane Receptors, Channels and Transporters in Pulmonary Circulation; Humana Press: Totowa, NJ, USA, 2010; pp. 309-322.

7. Xu, W.; Kaneko, F.T.; Zheng, S.; Comhair, S.A.; Janocha, A.J.; Goggans, T.; Thunnissen, F.B.; Farver, C.; Hazen, S.L.; Jennings, C. Increased Arginase II and Decreased NO Synthesis in Endothelial Cells of Patients with Pulmonary Arterial Hypertension. FASEB J. 2004, 18, 1746-1748. [CrossRef] [PubMed]

8. Martin, P.E.; Evans, W.H. Incorporation of Connexins into Plasma Membranes and Gap Junctions. Cardiovasc. Res. 2004, 62, 378-387. [CrossRef] [PubMed] 
9. Figueroa, X.F.; Duling, B.R. Gap Junctions in the Control of Vascular Function. Antioxid. Redox Signal. 2009, 11, 251-266. [CrossRef] [PubMed]

10. Brisset, A.C.; Isakson, B.E.; Kwak, B.R. Connexins in Vascular Physiology and Pathology. Antioxid. Redox Signal. 2009, 11, 267-282. [CrossRef] [PubMed]

11. Johnstone, S.; Isakson, B.; Locke, D. Biological and Biophysical Properties of Vascular Connexin Channels. Int. Rev. Cell Mol. Biol. 2009, 278, 69-118. [PubMed]

12. Sosinsky, G.E.; Boassa, D.; Dermietzel, R.; Duffy, H.S.; Laird, D.W.; MacVicar, B.; Naus, C.C.; Penuela, S.; Scemes, E.; Spray, D.C. Pannexin Channels are Not Gap Junction Hemichannels. Channels 2011, 5, $193-197$. [CrossRef] [PubMed]

13. Lohman, A.W.; Billaud, M.; Straub, A.C.; Johnstone, S.R.; Best, A.K.; Lee, M.; Barr, K.; Penuela, S.; Laird, D.W.; Isakson, B.E. Expression of Pannexin Isoforms in the Systemic Murine Arterial Network. J. Vasc. Res. 2012, 49, 405-416. [CrossRef] [PubMed]

14. Billaud, M.; Chiu, Y.H.; Lohman, A.W.; Parpaite, T.; Butcher, J.T.; Mutchler, S.M.; DeLalio, L.J.; Artamonov, M.V.; Sandilos, J.K.; Best, A.K.; et al. A Molecular Signature in the pannexin1 Intracellular Loop Confers Channel Activation by the alpha1 Adrenoreceptor in Smooth Muscle Cells. Sci. Signal. 2015, 8, ra17. [CrossRef] [PubMed]

15. Tsang, H.; Leiper, J.; Lao, K.H.; Dowsett, L.; Delahaye, M.W.; Barnes, G.; Wharton, J.; Howard, L.; Iannone, L.; Lang, N.N. Role of Asymmetric Methylarginine and Connexin 43 in the Regulation of Pulmonary Endothelial Function. Pulm. Circ. 2013, 3, 675-691. [CrossRef] [PubMed]

16. Kim, J.; Hwangbo, C.; Hu, X.; Kang, Y.; Papangeli, I.; Mehrotra, D.; Park, H.; Ju, H.; McLean, D.L.; Comhair, S.A.; et al. Restoration of Impaired Endothelial Myocyte Enhancer Factor 2 Function Rescues Pulmonary Arterial Hypertension. Circulation 2015, 131, 190-199. [CrossRef] [PubMed]

17. Wang, L.; Yin, J.; Nickles, H.T.; Ranke, H.; Tabuchi, A.; Hoffmann, J.; Tabeling, C.; Barbosa-Sicard, E.; Chanson, M.; Kwak, B.R.; et al. Hypoxic Pulmonary Vasoconstriction Requires Connexin 40-Mediated Endothelial Signal Conduction. J. Clin. Investig. 2012, 122, 4218-4230. [CrossRef] [PubMed]

18. Billaud, M.; Dahan, D.; Marthan, R.; Savineau, J.; Guibert, C. Role of the Gap Junctions in the Contractile Response to Agonists in Pulmonary Artery from Two Rat Models of Pulmonary Hypertension. Respir. Res. 2011, 12, 30. [CrossRef] [PubMed]

19. Mair, K.; MacLean, M.; Morecroft, I.; Dempsie, Y.; Palmer, T. Novel Interactions between the 5-HT Transporter, 5-HT1B Receptors and Rho Kinase in Vivo and in Pulmonary Fibroblasts. Br. J. Pharmacol. 2008, 155, 606-616. [CrossRef] [PubMed]

20. Sullivan, C.C.; Du, L.; Chu, D.; Cho, A.J.; Kido, M.; Wolf, P.L.; Jamieson, S.W.; Thistlethwaite, P.A. Induction of Pulmonary Hypertension by an Angiopoietin 1/TIE2/serotonin Pathway. Proc. Natl. Acad. Sci. USA 2003, 100, 12331-12336. [CrossRef] [PubMed]

21. Morecroft, I.; Dempsie, Y.; Bader, M.; Walther, D.J.; Kotnik, K.; Loughlin, L.; Nilsen, M.; MacLean, M.R. Effect of Tryptophan Hydroxylase 1 Deficiency on the Development of Hypoxia-Induced Pulmonary Hypertension. Hypertension 2007, 49, 232-236. [CrossRef] [PubMed]

22. Gairhe, S.; Bauer, N.N.; Gebb, S.A.; McMurtry, I.F. Serotonin Passes through Myoendothelial Gap Junctions to Promote Pulmonary Arterial Smooth Muscle Cell Differentiation. Am. J. Physiol. Lung Cell Mol. Physiol. 2012, 303, L767-L777. [CrossRef] [PubMed]

23. Gairhe, S.; Bauer, N.N.; Gebb, S.A.; McMurtry, I.F. Myoendothelial Gap Junctional Signaling Induces Differentiation of Pulmonary Arterial Smooth Muscle Cells. Am. J. Physiol. Lung Cell Mol. Physiol 2011, 301, L527-L535. [CrossRef] [PubMed]

24. Reaume, A.G.; de Sousa, P.A.; Kulkarni, S.; Langille, B.L.; Zhu, D.; Davies, T.C.; Juneja, S.C.; Kidder, G.M.; Rossant, J. Cardiac Malformation in Neonatal Mice Lacking connexin43. Science 1995, 267, 1831-1834. [CrossRef] [PubMed]

25. Yang, Y.M.; Yuan, H.; Edwards, J.G.; Skayian, Y.; Ochani, K.; Miller, E.J.; Sehgal, P.B. Deletion of STAT5a/b in Vascular Smooth Muscle Abrogates the Male Bias in Hypoxic Pulmonary Hypertension in Mice: Implications in the Human Disease. Mol. Med. 2015, 20, 625-638. [PubMed]

26. Ma, L.; Chung, W.K. The Genetic Basis of Pulmonary Arterial Hypertension. Hum. Genet. 2014, 133, 471-479. [CrossRef] [PubMed]

27. Orriols, M.; Gomez-Puerto, M.C.; ten Dijke, P. BMP Type II Receptor as a Therapeutic Target in Pulmonary Arterial Hypertension. Cell. Mol. Life Sci. 2017, 74, 2979-2995. [CrossRef] [PubMed] 
28. Figueroa, X.F.; Lillo, M.A.; Gaete, P.S.; Riquelme, M.A.; Sáez, J.C. Diffusion of Nitric Oxide Across Cell Membranes of the Vascular Wall Requires Specific Connexin-Based Channels. Neuropharmacology 2013, 75, 471-478. [CrossRef] [PubMed]

29. Looft-Wilson, R.; Billaud, M.; Johnstone, S.; Straub, A.; Isakson, B. Interaction between Nitric Oxide Signaling and Gap Junctions: Effects on Vascular Function. Biochim. Biophys. Acta 2012, 1818, 1895-1902. [CrossRef] [PubMed]

30. Straub, A.C.; Billaud, M.; Johnstone, S.R.; Best, A.K.; Yemen, S.; Dwyer, S.T.; Looft-Wilson, R.; Lysiak, J.J.; Gaston, B.; Palmer, L.; et al. Compartmentalized Connexin 43 S-nitrosylation/denitrosylation Regulates Heterocellular Communication in the Vessel Wall. Arterioscler. Thromb. Vasc. Biol. 2011, 31, 399-407. [CrossRef] [PubMed]

31. Hoffmann, A.; Gloe, T.; Pohl, U.; Zahler, S. Nitric Oxide Enhances De Novo Formation of Endothelial Gap Junctions. Cardiovasc. Res. 2003, 60, 421-430. [CrossRef] [PubMed]

32. Alonso, F.; Boittin, F.X.; Beny, J.L.; Haefliger, J.A. Loss of connexin40 is Associated with Decreased Endothelium-Dependent Relaxations and eNOS Levels in the Mouse Aorta. Am. J. Physiol. Heart Circ. Physiol. 2010, 299, H1365-H1373. [CrossRef] [PubMed]

33. Kameritsch, P.; Khandoga, N.; Nagel, W.; Hundhausen, C.; Lidington, D.; Pohl, U. Nitric Oxide Specifically Reduces the Permeability of Cx37-containing Gap Junctions to Small Molecules. J. Cell. Physiol. 2005, 203, 233-242. [CrossRef] [PubMed]

34. McKinnon, R.L.; Bolon, M.L.; Wang, H.X.; Swarbreck, S.; Kidder, G.M.; Simon, A.M.; Tyml, K. Reduction of Electrical Coupling between Microvascular Endothelial Cells by NO Depends on connexin37. Am. J. Physiol. Heart Circ. Physiol. 2009, 297, H93-H101. [CrossRef] [PubMed]

35. Leblais, V.; Delannoy, E.; Fresquet, F.; Bégueret, H.; Bellance, N.; Banquet, S.; Allieres, C.; Leroux, L.; Desgranges, C.; Gadeau, A. B-Adrenergic Relaxation in Pulmonary Arteries: Preservation of the Endothelial Nitric Oxide-Dependent $\beta 2$ Component in Pulmonary Hypertension. Cardiovasc. Res. 2007, 77, 202-210. [CrossRef] [PubMed]

36. Mair, K.; Johansen, A.; Wright, A.; Wallace, E.; MacLean, M. Pulmonary Arterial Hypertension: Basis of Sex Differences in Incidence and Treatment Response. Br. J. Pharmacol. 2014, 171, 567-579. [CrossRef] [PubMed]

37. Polderman, K.H.; Stehouwer, C.D.; van Kamp, G.J.; Dekker, G.A.; Verheugt, F.W.; Gooren, L.J. Influence of Sex Hormones on Plasma Endothelin Levels. Ann. Intern. Med. 1993, 118, 429-432. [CrossRef] [PubMed]

38. Miyauchi, T.; Yanagisawa, M.; Iida, K.; Ajisaka, R.; Suzuki, N.; Fujino, M.; Goto, K.; Masaki, T.; Sugishita, Y. Age-and Sex-Related Variation of Plasma Endothelin-1 Concentration in Normal and Hypertensive Subjects. Am. Heart J. 1992, 123, 1092-1093. [CrossRef]

39. Ergul, A.; Shoemaker, K.; Puett, D.; Tackett, R.L. Gender Differences in the Expression of Endothelin Receptors in Human Saphenous Veins in Vitro. J. Pharmacol. Exp. Ther. 1998, 285, 511-517. [PubMed]

40. Tatchum-Talom, R.; Martel, C.; Labrie, C.; Labrie, F.; Marette, A. Gender Differences in Hemodynamic Responses to Endothelin-1. J. Cardiovasc. Pharmacol. 2000, 36, S102-S104. [CrossRef] [PubMed]

41. Juan, S.; Chen, J.; Chen, C.; Lin, H.; Cheng, C.; Liu, J.; Hsieh, M.; Chen, Y.; Chao, H.; Chen, T. 17 $\beta$-Estradiol Inhibits Cyclic Strain-Induced Endothelin-1 Gene Expression within Vascular Endothelial Cells. Am. J. Physiol. 2004, 287, H1254-H1261. [CrossRef] [PubMed]

42. Axelsen, L.N.; Calloe, K.; Holstein-Rathlou, N.; Nielsen, M.S. Managing the Complexity of Communication: Regulation of Gap Junctions by Post-Translational Modification. Front. Pharmacol. 2013, 4, 130. [CrossRef] [PubMed]

43. Van Kempen, M.J.; Jongsma, H.J. Distribution of connexin37, connexin40 and connexin43 in the Aorta and Coronary Artery of several Mammals. Histochem. Cell Biol. 1999, 112, 479-486.

44. Hill, C.; Rummery, N.; Hickey, H.; Sandow, S.L. Heterogeneity in the Distribution of Vascular Gap Junctions and Connexins: Implications for Function. Clin. Exp. Pharmacol. Physiol. 2002, 29, 620-625. [CrossRef] [PubMed]

45. Yeh, H.I.; Rothery, S.; Dupont, E.; Coppen, S.R.; Severs, N.J. Individual Gap Junction Plaques Contain Multiple Connexins in Arterial Endothelium. Circ. Res. 1998, 83, 1248-1263. [CrossRef] [PubMed]

46. Chaytor, A.T.; Bakker, L.M.; Edwards, D.H.; Griffith, T.M. Connexin-mimetic Peptides Dissociate Electrotonic EDHF-type Signalling Via Myoendothelial and Smooth Muscle Gap Junctions in the Rabbit Iliac Artery. Br. J. Pharmacol. 2005, 144, 108-114. [CrossRef] [PubMed] 
47. Stauffer, B.L.; Sobus, R.D.; Sucharov, C.C. Sex Differences in Cardiomyocyte connexin43 Expression. J. Cardiovasc. Pharmacol. 2011, 58, 32-39. [CrossRef] [PubMed]

48. Di, W.; Lachelin, G.C.; McGarrigle, H.; Thomas, N.; Becker, D. Oestriol and Oestradiol Increase Cell to Cell Communication and connexin43 Protein Expression in Human Myometrium. Mol. Hum. Reprod. 2001, 7, 671-679. [CrossRef] [PubMed]

49. Yu, W.; Dahl, G.; Werner, R. The connexin43 Gene is Responsive to Oestrogen. Proc. Biol. Sci. 1994, 255, 125-132. [CrossRef] [PubMed]

50. Matsushita, S.; Kurihara, H.; Watanabe, M.; Okada, T.; Sakai, T.; Amano, A. Alterations of Phosphorylation State of Connexin 43 during Hypoxia and Reoxygenation are Associated with Cardiac Function. J. Histochem. Cytochem. 2006, 54, 343-353. [CrossRef] [PubMed]

51. Faigle, M.; Seessle, J.; Zug, S.; El Kasmi, K.C.; Eltzschig, H.K. ATP Release from Vascular Endothelia Occurs Across Cx43 Hemichannels and is Attenuated during Hypoxia. PLoS ONE 2008, 3, e2801. [CrossRef] [PubMed]

52. Li, N.; Dai, D.; Dai, Y. CPU86017 and its Isomers Improve Hypoxic Pulmonary Hypertension by Attenuating Increased ETA Receptor Expression and Extracellular Matrix Accumulation. Naunyn Schmiedebergs Arch. Pharmacol. 2008, 378, 541. [CrossRef] [PubMed]

53. Yang, L.; Yin, N.; Hu, L.; Fan, H.; Yu, D.; Zhang, W.; Wang, S.; Feng, Y.; Fan, C.; Cao, F.; et al. Sildenefil Increases Connexin 40 in Smooth Muscle Cells through Activation of BMP Pathways in Pulmonary Arterial Hypertension. Int. J. Clin. Exp. Pathol. 2014, 7, 4674-4684. [PubMed]

54. Schmidt, V.J.; Jobs, A.; von Maltzahn, J.; Wörsdörfer, P.; Willecke, K.; de Wit, C. Connexin45 is Expressed in Vascular Smooth Muscle but its Function Remains Elusive. PLoS ONE 2012, 7, e42287. [CrossRef] [PubMed]

55. MacLean, M.R.; Deuchar, G.A.; Hicks, M.N.; Morecroft, I.; Shen, S.; Sheward, J.; Colston, J.; Loughlin, L.; Nilsen, M.; Dempsie, Y.; et al. Overexpression of the 5-Hydroxytryptamine Transporter Gene: Effect on Pulmonary Hemodynamics and Hypoxia-Induced Pulmonary Hypertension. Circulation 2004, 109, 2150-2155. [CrossRef] [PubMed]

56. Dempsie, Y.; Nilsen, M.; White, K.; Mair, K.M.; Loughlin, L.; Ambartsumian, N.; Rabinovitch, M.; MacLean, M.R. Development of Pulmonary Arterial Hypertension in Mice Over-Expressing S100A4/Mts1 is Specific to Females. Respir. Res. 2011, 12, 159. [CrossRef] [PubMed]

57. Dempsie, Y.; MacRitchie, N.A.; White, K.; Morecroft, I.; Wright, A.F.; Nilsen, M.; Loughlin, L.; Mair, K.M.; MacLean, M.R. Dexfenfluramine and the Oestrogen-Metabolizing Enzyme CYP1B1 in the Development of Pulmonary Arterial Hypertension. Cardiovasc. Res. 2013, 99, 24-34. [CrossRef] [PubMed]

58. Michela, P.; Velia, V.; Aldo, P.; Ada, P. Role of Connexin 43 in Cardiovascular Diseases. Eur. J. Pharmacol. 2015, 768, 71-76. [CrossRef] [PubMed]

59. Isakson, B.E.; Damon, D.N.; Day, K.H.; Liao, Y.; Duling, B.R. Connexin40 and connexin43 in Mouse Aortic Endothelium: Evidence for Coordinated Regulation. Am J. Physiol. 2006, 290, H1199-H1205. [CrossRef] [PubMed]

60. Kruger, O.; Beny, J.L.; Chabaud, F.; Traub, O.; Theis, M.; Brix, K.; Kirchhoff, S.; Willecke, K. Altered Dye Diffusion and Upregulation of connexin37 in Mouse Aortic Endothelium Deficient in connexin40. J. Vasc. Res. 2002, 39, 160-172. [CrossRef] [PubMed]

61. Simon, A.M.; McWhorter, A.R. Decreased Intercellular Dye-Transfer and Downregulation of Non-Ablated Connexins in Aortic Endothelium Deficient in connexin37 or connexin40. J. Cell Sci. 2003, 116, 2223-2236. [CrossRef] [PubMed]

62. Giaid, A.; Saleh, D. Reduced Expression of Endothelial Nitric Oxide Synthase in the Lungs of Patients with Pulmonary Hypertension. N. Engl. J. Med. 1995, 333, 214-221. [CrossRef] [PubMed]

63. Zhao, Y.Y.; Zhao, Y.D.; Mirza, M.K.; Huang, J.H.; Potula, H.H.; Vogel, S.M.; Brovkovych, V.; Yuan, J.X.; Wharton, J.; Malik, A.B. Persistent eNOS Activation Secondary to Caveolin-1 Deficiency Induces Pulmonary Hypertension in Mice and Humans through PKG Nitration. J. Clin. Investig. 2009, 119, 2009-2018. [CrossRef] [PubMed]

64. Mason, N.A.; Springall, D.R.; Burke, M.; Pollock, J.; Mikhail, G.; Yacoub, M.H.; Polak, J.M. High Expression of Endothelial Nitric Oxide Synthase in Plexiform Lesions of Pulmonary Hypertension. J. Pathol. 1998, 185, 313-318. [CrossRef] 
65. Kaneko, F.T.; Arroliga, A.C.; Dweik, R.A.; Comhair, S.A.; Laskowski, D.; Oppedisano, R.; Thomassen, M.J.; Erzurum, S.C. Biochemical Reaction Products of Nitric Oxide as Quantitative Markers of Primary Pulmonary Hypertension. Am. J. Respir. Crit. Care Med. 1998, 158, 917-923. [CrossRef] [PubMed]

66. Austin, E.D.; Hamid, R.; Hemnes, A.R.; Loyd, J.E.; Blackwell, T.; Yu, C.; Phillips III, J.A.; Gaddipati, R.; Gladson, S.; Gu, E. BMPR2 Expression is Suppressed by Signaling through the Estrogen Receptor. Biol. Sex Differ. 2012, 3, 6. [CrossRef] [PubMed]

67. Keegan, A.; Morecroft, I.; Smillie, D.; Hicks, M.N.; MacLean, M.R. Contribution of the 5-HT(1B) Receptor to Hypoxia-Induced Pulmonary Hypertension: Converging Evidence using 5-HT(1B)-Receptor Knockout Mice and the 5-HT(1B/1D)-Receptor Antagonist GR127935. Circ. Res. 2001, 89, 1231-1239. [CrossRef] [PubMed]

68. Morecroft, I.; Pang, L.; Baranowska, M.; Nilsen, M.; Loughlin, L.; Dempsie, Y.; Millet, C.; MacLean, M.R. In Vivo Effects of a Combined 5-HT1B receptor/SERT Antagonist in Experimental Pulmonary Hypertension. Cardiovasc. Res. 2009, 85, 593-603. [CrossRef] [PubMed]

69. Chaytor, A.T.; Evans, W.H.; Griffith, T.; Thornbury, K. Peptides Homologous to Extracellular Loop Motifs of Connexin 43 Reversibly Abolish Rhythmic Contractile Activity in Rabbit Arteries. J. Physiol. 1997, 503, 99-110. [CrossRef] [PubMed]

70. Glass, B.J.; Hu, R.G.; Phillips, A.R.; Becker, D.L. The Action of Mimetic Peptides on Connexins Protects Fibroblasts from the Negative Effects of Ischemia Reperfusion. Biol. Open 2015, 4, 1473-1480. [CrossRef] [PubMed]

71. Faniku, C.; O'Shaughnessy, E.; Lorraine, C.; Johnstone, S.R.; Graham, A.; Greenhough, S.; Martin, P.E. The Connexin Mimetic Peptide Gap27 and Cx43-Knockdown Reveal Differential Roles for Connexin43 in Wound Closure Events in Skin Model Systems. Int. J. Mol. Sci. 2018, 19, 604. [CrossRef] [PubMed]

72. Wright, C.S.; Pollok, S.; Flint, D.J.; Brandner, J.M.; Martin, P.E. The Connexin Mimetic Peptide Gap27 Increases Human Dermal Fibroblast Migration in Hyperglycemic and Hyperinsulinemic Conditions in Vitro. J. Cell. Physiol. 2012, 227, 77-87. [CrossRef] [PubMed]

(C) 2018 by the authors. Licensee MDPI, Basel, Switzerland. This article is an open access article distributed under the terms and conditions of the Creative Commons Attribution (CC BY) license (http:// creativecommons.org/licenses/by/4.0/). 